\title{
Article \\ Effects of Forestry Transformation on the Landscape Level of Biodiversity in Poland's Forests
}

\author{
Ewa Referowska-Chodak ${ }^{1, *(D)}$ and Bożena Kornatowska ${ }^{2}$ \\ 1 Institute of Forest Sciences, Warsaw University of Life Sciences, Nowoursynowska 159, \\ 02-776 Warszawa, Poland \\ 2 Institute of Environmental Protection-National Research Institute, Krucza 5/11D, 00-548 Warszawa, Poland; \\ bozena.kornatowska@ios.edu.pl \\ * Correspondence: ewa_referowska_chodak@sggw.edu.pl
}

Citation: Referowska-Chodak, E.; Kornatowska, B. Effects of Forestry Transformation on the Landscape Level of Biodiversity in Poland's Forests. Forests 2021, 12, 1682. https://doi.org/10.3390/f12121682

Academic Editors: Konstantinos Poirazidis and Panteleimon Xofis

Received: 13 November 2021 Accepted: 27 November 2021 Published: 1 December 2021

Publisher's Note: MDPI stays neutral with regard to jurisdictional claims in published maps and institutional affiliations.

Copyright: (c) 2021 by the authors. Licensee MDPI, Basel, Switzerland. This article is an open access article distributed under the terms and conditions of the Creative Commons Attribution (CC BY) license (https:/ / creativecommons.org/licenses/by/ $4.0 /)$.

\begin{abstract}
At all times, historical, political, economic, and social factors have affected the management of forests, with direct and indirect effects on the landscape. This study aimed to trace the impact of Poland's forestry evolution over the last 75 years (1945-2020) on forest biodiversity at the landscape level. Five indicators were selected (forest area, forest fragmentation, protected forests, protective forests, harvesting intensity) to identify directions and dynamics of changes of the forest landscape and their determinants and repercussions. In addition, there were determined forest landscapes threats and recommendations for further action and intervention were formulated. The study period embraced two eras of widely divergent political-economic conditions in Poland (socialism and democracy). In the socialism era (1945-1989), there promptly increased total forest cover, wood resources (total growing stock) and the total area of protective forests (essential for safeguarding biodiversity, including the landscape level). In the era of democracy (1990-2020), average growing stock density increased intensely, and at the same time, a greater emphasis was put on reducing forest fragmentation and clear-cut logging. The results obtained showed equal average increase in the area of protected forests in both eras under the study (most intense at their crossing point). In view of the protection of biodiversity at the forest landscape level, the changes throughout the study period were considered positive, although not without problems and challenging consequences for foresters. The determined pressures to the forest landscapes, requiring legal, political, or financial solutions, include a risk of alteration of the ownership structure of Poland's forests or possibility of operational changes in the State Forests National Forest Holding; outdated forest policies; organizational difficulties in the forest landscape protection; insufficient conservation funding; uneven distribution and further fragmentation of forests; and-last but not least—climate change impacts, including extreme weather events and droughts.
\end{abstract}

Keywords: SFM indicator; forest area; forest fragmentation; protected forest; protective forest; harvesting intensity

\section{Introduction}

Forests play an exceptional role in maintaining biodiversity [1], including that at the landscape level. Fulfillment of this function has always been affected by the way of forests management (e.g., [2]), reliant upon inevitably changing historical, political, economic, and social conditions. As a consequence, forest management has been reflected in functioning and diversity of forests and their role in shaping the landscape. A comprehensive analysis of these relationships, carried out in consideration of conceivable conflicts, the long-term perspective and large spatial scale, can be a source of insights and inspirations-useful for forest management improvement, not only within boundaries of a given country, but also at a level of, e.g., the continent. The present study attempted to depict these issues by the example of Poland (Central Europe-Figure 1). 


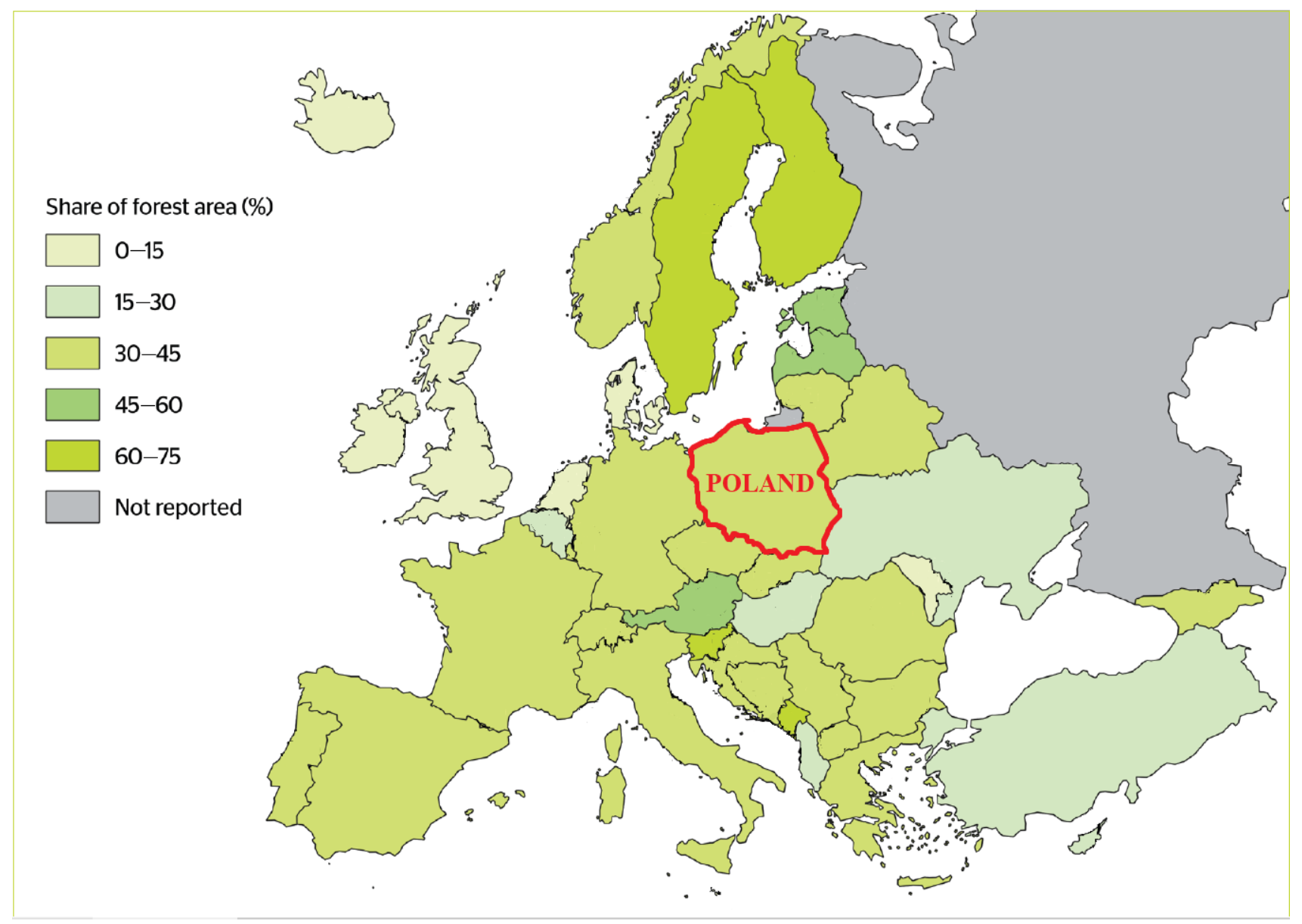

Figure 1. Poland's forest area as compared to other countries of Europe (source: [1], modified).

In the long ago past, almost entire area of then Poland was covered by primeval forests, except for high altitude mountainous region [3]. On account of the country development, already at the end of the 1700s, the forest cover within its then borders was $40 \%$ [4]. At that time, Poland was partitioned between the bordering empires (Russia, Prussia and Austria), who intensively exploited local environment for 123 years (1772-1918) [5-7]. It resulted in, inter alia, the simplification and standardization of Poland's forest landscape [8-11].

The foundations for the Polish model of multifunctional forestry were laid between 1918 and 1938. In 1924, there was established the Polish State Forests Enterprise who is still functioning as the State Forests National Forest Holding (State Forests, SF, also in the sense of forests managed by this enterprise). The development of Polish forestry was interrupted by the World War II (WW2). In 1939-1945, Poland's forests were very demolished by warfare and military battles fought on the Eastern Front, as well as were indiscriminately exploited by the German occupying forces. As compared to that at the end of the 1700s, Poland's forest cover as of 1945 was reduced almost by two (from approximately $40 \%$ to 20.8\%) [12-14].

In the years 1945-1989, there was implemented a socialist model of economy in Poland, centrally planned and regulated, characterized by strong nationalization and industrialization of the country $[12,15,16]$. Forest management at that time followed a resource-based economic model $[8,17]$. Sustainability and ecological principles were of secondary importance [17], as only the achievement of production goals mattered [18]. At the same time, increasing environmental pollution entailed a strong deterioration of forest health $[19,20]$, in extreme situations leading to loss of entire stands. Consequently, forest biodiversity at all levels was declining, regardless of efforts undertaken by forest managers to alleviate the problem. 
At the end of the 1980s, only the historic change of Poland's political system, i.e., the transition from socialism into democracy, allowed for intensification of efforts towards sustainable management of national forests. This coincided with active participation of Poland in the works of the Convention on Biological Diversity (CBD) and the Ministerial Conference on the Protection of Forests in Europe (MCPFE-now FOREST EUROPE), associated with taking responsibility for the commitments imposed under the framework of these processes. Starting from the beginning of the 1990s, the importance of forest biodiversity and ecosystem services was recognized through the adoption of relevant legislation: the Forest Act [21], which stressed the necessity for permanent preservation of forests and included the concept of sustainable forest management (SFM) as well as emphasized the need of its implementation in Poland's forests; National Forest Policy [22], which gave high priority to efforts towards improving forest biodiversity [23], and the orders by the Director General with regard to the best ecological practices in forest management [24,25].

The beginning of 21st century brought further political changes in Poland-the accession to the European Union (EU) in 2004, preceded, among others, by comprehensive works concerning the implementation of the Habitats and the Birds Directives. Both directives have played a fundamental role in the enforcement of nature conservation in national forests [26]. In the context of the present study, ratification (2003) of the Aarhus Convention [27] was of great importance, as then Poland's society was provided for tools to impose demands for forest management with the use of ecological solutions.

In view of the above, the main objective of the present study was to evaluate effects of evolution of forestry under Poland's conditions on forest biodiversity at the landscape level, with the use selected indicators. In the perspective of 75 years, the specific objectives were distinguished: (1) to determine the direction and dynamics of changes in the forest landscape, (2) to identify the determinants of the observed changes and their impacts (3) to identify threats to the forest landscape and the direction of further action for its benefit.

\section{Materials and Methods}

\subsection{Indicators}

At a European level, assessing and reporting progress on sustainable forest management at regional and national levels has been carried out with the use of a set of criteria and indicators (C\&I), among which those concerning the status of forest biodiversity reflect the state of more than one of its levels [28,29]. For instance, C\&I Criterion C4: Maintenance, conservation, and appropriate enhancement of biological diversity in forest ecosystems describes a variety of existing life forms as well as their ecological roles and genetic diversity. In this context, e.g., forest stand species composition (Indicator 4.1 Diversity of tree species) can be considered in view of both species diversity and ecosystem diversity, taking into consideration the effect of individual species on the spatial structure of the entire ecosystem. For the purpose of the present study, the influence of forest management evolution in Poland, especially in forests managed by the State Forests National Forest Holding, on forest biodiversity at the landscape level was based on selected indicators that relate to different levels of forest biodiversity, and especially to that at the landscape level.

The effects of Polish forestry evolution on forest biodiversity at the landscape level were evaluated with reference to the indicators in the set of C\&I for SFM [28] and those proposed by Mederski et al. [17]. Bearing in mind the influence of the ecological course of action on the forest landscapes, the following indicators were chosen:

1. Forest area-indicator for SFM (C\&I CRITERION 1 Maintenance and Appropriate Enhancement of Forest Resources and their Contribution to Global Carbon Cycles, Indicator 1.1 Forest area [28]). For the purpose of this study the term "forest area" refers to the area (ha) physically covered by forests (or temporarily deprived of them), exclusive of lands associated with forest management, defined as "Land occupied for use for forest management purposes: buildings and structures, forest zoning lines, forest roads, forest nurseries, timber storage areas, water reclamation facilities, land under power lines, forest parking lots, and tourist facilities." (Forest Act [21]). Being the 
most complex plant formation, forests constitute an indispensable component of the landscape. Their area represents their share in the landscape, in other words forest cover is understood as the percentage ratio (\%) of forest area to the total geodetic area of the country [30];

2. Forest fragmentation-indicator for SFM (C\&I, Indicator 4.7 Forest fragmentation [28]. There were examined: the number of forest patches (items), average forest patch size (ha), the share of separated forest patches and of continuous forest (\%), as well as by the share of forests patches of different size in total forest area (\%). The way the forest is shaped (continuous stands vs. isolated patches, smaller vs. larger patches) is not without influence on landscape mosaicity. Forest fragmentation translates into conditions for maintenance and enhancement of ecosystems, species and gene pool;

3. Protected forests - indicator for SFM (C\&I, Indicator 4.9 Protected forests [28]). This indicator was considered in view of a broader approach assumed by Mederski et al. [17], i.e., "Forest functions-protection vs. economic role". In this study, the emphasis was put on nature conservation forms that are crucial for the protection of forest biodiversity as well as changes of their area (ha). At the landscape level, protected forests can be distinguished from managed forests, by giving the impression of "more natural". At the same time they provide favorable conditions to support natural processes and safeguard valuable habitats and species;

4. Protective forests-indicator for SFM (C\&I, Indicator 5.1 Protective forests-soil, water, and other ecosystem functions - infrastructure and managed natural resources [28]). Likewise in the case of C\&I Indicator 4.9, this one was considered in view of a broader context proposed by Mederski et al. [17] "Forest functions-protection vs. economic role". The present paper focused on the protective forests established with the aim to enhance biodiversity conservation, and they were characterized with reference to changes in their surface area (ha). The protective forests analyzed under this study are to a big extent analogous to protected forests;

5. Harvesting intensity - this indicator covers a complex issue, for which the most important indicator is the intensity of the use of annual wood increment (fellings as percent of net annual increment). It refers to: C\&I for SFM [28], i.e., CRITERION 3 Maintenance and Encouragement of Productive Functions of Forests (Wood and Non-Wood), Indicator 3.1 Increment and fellings. Based on the latter and taking into account total growing stock in $\mathrm{m}^{3}$ (C\&I Indicator 1.2 Growing stock [28]), harvested timber volume (net, without bark, in $\mathrm{m}^{3}$ - as in the indicator Wood production proposed by Mederski et al. [17]), as well as average growing stock density (standing timber volume $\mathrm{m}^{3}$ per ha of forest area), was assessed in view of relationships between harvesting intensity and sustainability and quality of the forest landscape.

\subsection{Scope of Analyses}

The present study focused on analyzing the effects of forest management evolution in state-owned forests (SF), mainly due to easier access to reliable information and data, as well as the homogeneity of forest management objectives pursued at a large spatial scale. The State Forests is the largest specialized public forest management entity in the EU [31]. Today it manages almost 77\% of the total forest area in Poland [30]. The references to the country as a whole were made only when relevant information on state-owned forests (SF) was unavailable or in the cases pertinent for the results presented.

The study period covered the period 1945-2020 of Poland's history. There was assumed that the effects of forestry evolution on forest biodiversity should be presented based on data compiled in 10-year intervals, marked by the following years: 1950 (state reconstruction after the World War II; socialist economy model forced; reforestation/afforestation activities undertaken), 1960 (socialist economy model fully implemented; increased forest cover), 1970 (socialist economy model; deterioration of forest health), 1980 (initial political and economic changes; starting point for environmental protection), 1990 (transformation towards free market economy; instigation of key changes in forest management), 
2000 (preparations for Poland's accession to the EU and adoption of EU legislation), 2010 (further greening of forest management and counteracting climate change; continuation of establishing Natura 2000 sites; implementing the Aarhus Convention) and 2020 (continuation of forest sustainable management; increased pressure of the society on the protection of national forests). The analysis of the results obtained focused on the two periods in the history of Polish forestry-the era of socialism (1945-1989) and the era of democracy (1989-2020). The year 1990 was assumed as the milestone in the adopted timeline.

In the case of lacking data for the selected study years, information was supplemented based on available data for the years as close as possible to those studied. The tables show data referring to the end of a given year. In some cases, this did not apply to the year 2020 due to so far absence of statistical summaries, hence, information for the beginning of 2020 was presented. Due to specifics of national statistics system operating in the late 1950s and early 1960s (the marketing year covered the last quarter of the previous year and the first three quarters of the following year), available data on wood resources and harvesting in the year 1960 were calculated as a sum of $\frac{3}{4}$ values of the parameter for the marketing year $1959 / 1960$ and $\frac{1}{4}$ values for the year 1960/1961.

The substantive scope of the work included: evaluating information/data compiled in terms of characteristics of the feature analyzed, taking into account variation over time as well as the direction and dynamics of changes; providing a comprehensive analytical commentary; identifying threats to the forest landscape and indicating directions of beneficial actions.

\subsection{Sources of Information}

The presented numerical data come from statistical Yearbooks on forestry and environmental protection published mainly by Statistics Poland (GUS), the reports published the State Forests National Forest Holding including those financial/economic, the Forest Data Bank [32], information regarding forest status update [33-36], monographs and articles prepared for the needs of the reports State of Europe's Forests (SoEF) prepared by MCPFE/FOREST EUROPE [1]. Due the lack of relevant studies/reports for the years at the beginning of the study period, some data were not available, nevertheless, the trend and dynamics of changes could still be revealed. For the purpose of the discussion of the results, there were used the results of several articles from Scopus database (keyword: Polish forestry), as well as those found using a snowballing approach.

\section{Results and Discussion}

\subsection{Forest Area}

The change in forest area is one of the key elements affecting the increase, maintenance or decline of the number, quality, and intensity of ecosystem services provided by forests, including those associated with the landscape. Ever since until 1945, Poland's forest area had gradually declined, and this general trend could not be reversed even by local forest succession on abandoned agricultural lands [37-39]. In 1945, the country's forest area reached its lowest ever value. At that time, 5408 thousand ha of forests remained under SF administration, which was $83.6 \%$ of existing forests in Poland [40,41]. In the following years the area of state-owned forests (SF) as well as of those privately owned progressively increased (Table 1). 
Table 1. The area of forests administered by SF as compared to all Poland's forests *

\begin{tabular}{ccccccccc}
\hline Year & $\mathbf{1 9 5 0}$ & $\mathbf{1 9 6 0}$ & $\mathbf{1 9 7 0}$ & $\mathbf{1 9 8 0}$ & $\mathbf{1 9 9 0}$ & $\mathbf{2 0 0 0}$ & $\mathbf{2 0 1 0}$ & $\mathbf{2 0 2 0}$ \\
\hline $\begin{array}{c}\text { Forest area [thousand ha] } \\
\quad 6915\end{array}$ & 7684 & 8432 & 8622 & 8694 & 8865 & 9121 & 9260 \\
$\quad$ Forest cover [\%] & 22.2 & 24.6 & 27.0 & 27.6 & 27.8 & 28.4 & 29.2 & 29.6 \\
$\begin{array}{c}\text { Forests managed by SF } \\
\quad \text { thousand ha] }\end{array}$ & 5740 & 6136 & 6503 & 6716 & 6805 & 6953 & 7072 & 7121 \\
$\begin{array}{c}\text { Share of forests managed } \\
\text { by SF in total forest area [\%] }\end{array}$ & 83.0 & 79.9 & 77.1 & 78.0 & 78.3 & 78.4 & 77.5 & 76.9 \\
\hline * sources: [19,41-46]. & & & & & & & & \\
\hline
\end{tabular}

The area of forests. Taking into consideration the whole study period, in 2020, the area of Polish forests managed by SF (Table 1) was almost 132\% of that in 1945 (average annual expansion: $0.42 \%$ ). However, once evaluated against the background of transition from socialism/state-directed economy to democracy/free market economy, the forest area managed by SF in 1990 was almost $126 \%$ of that in 1945 (average annual expansion: 0.57\%). In the subsequent 30 years (1990-2020), forest area increased just by $5 \%$ (average annual expansion: $0.15 \%$ ).

Over the study period, the significant increase of the area of Poland's forests (Figure 2) was primarily associated with intensive afforestation (mainly by planting young trees) on state-owned (including nationalized) non-forest lands, carried out in the period from 1945 to the late 1970s [7,12]. In the 1980s, Polish economy began to collapse, followed by the crisis in the country's development, intensified in the second half of the 1980s, which among others, caused a downfall in the timber market and, consequently, an evident decrease in the number of tasks carried out by SF [12]. Another increase in the extent of afforestation (mainly by planting) took place between 1995 and 2005 (free-market economy). This was due to the adoption and implementation of the National Program of the Augmentation of Forest Cover [47]. The main objective of the Program was to increase forest cover to $30 \%$ by 2020 and then to $33-34 \%$ by $2050[7,48,49]$.

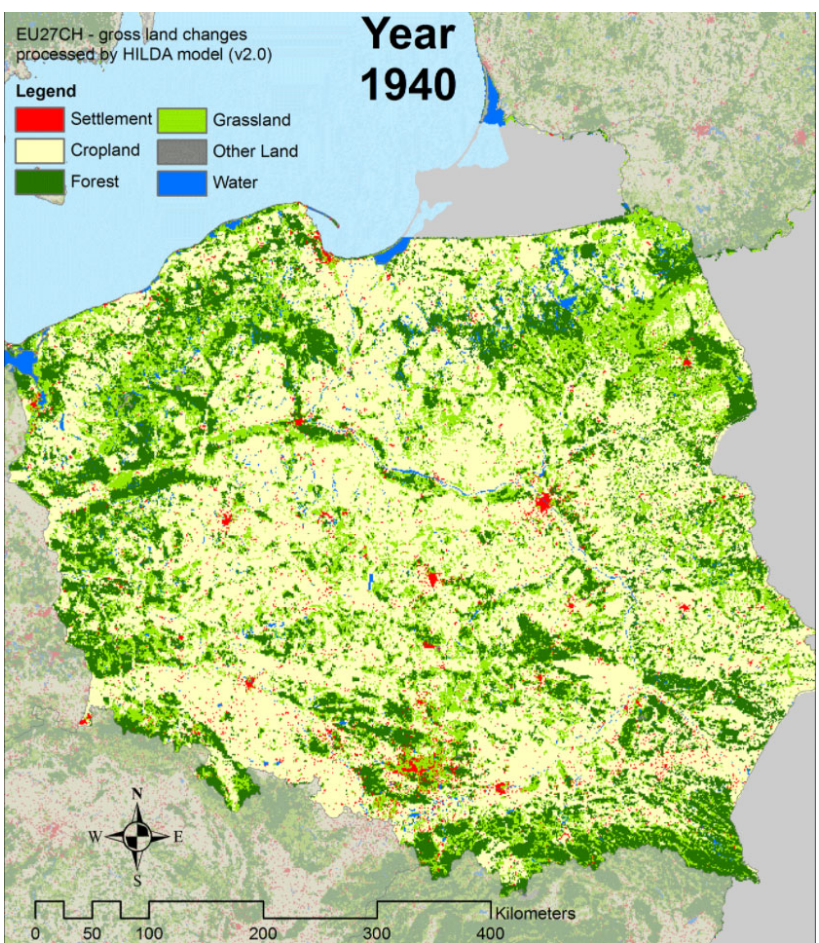

(a)

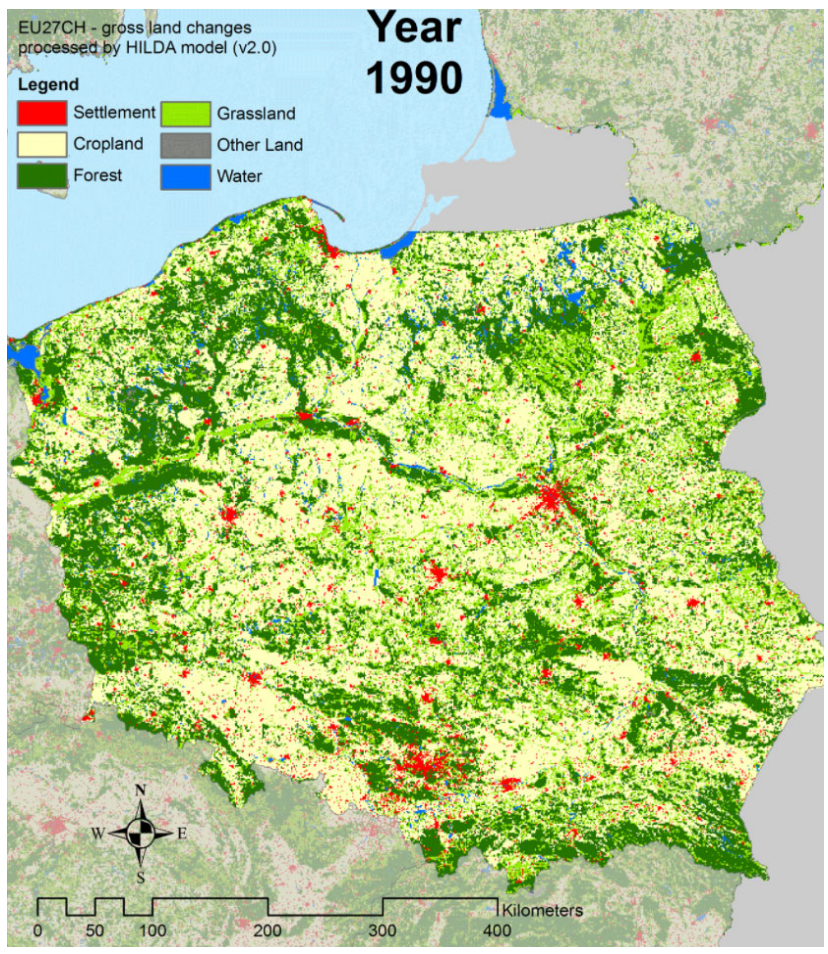

(b)

Figure 2. Cont. 


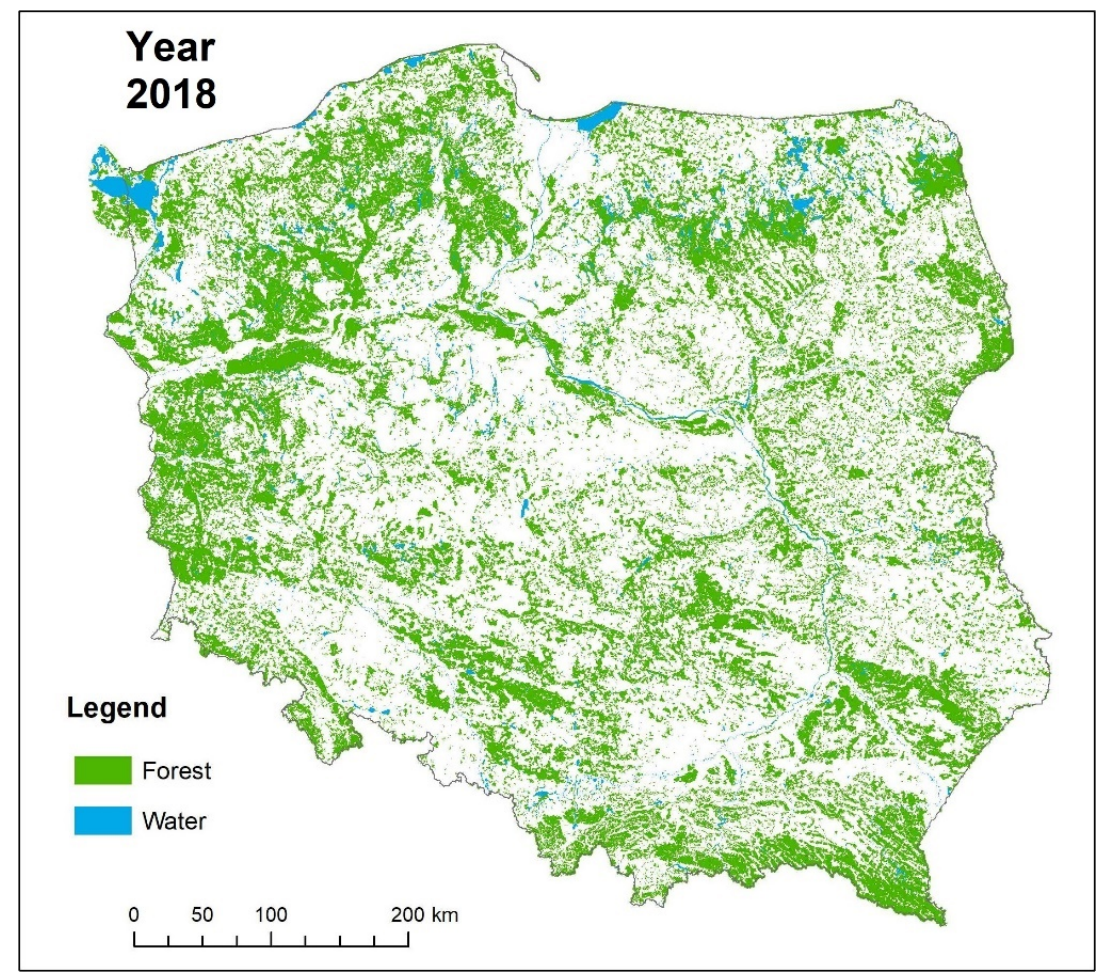

(c)

Figure 2. (a) Reconstruction of historic land cover of Poland in 1940 (based on [50]); (b) Reconstruction of historic land cover of Poland in 1990 (based on [50]); (c) Forest cover of Poland in 2018 (based on [51]).

Over the past years, forest expansion in Poland has slowed down as it has across Europe [1]. In Poland, this has been due to: higher EU subsidies for keeping land in agricultural production; an unfavorable change in the minimum area for afforestation subsidies; reduction of the maximum area designated to reforestation/afforestation; elimination of financial support for afforestation of permanent grassland; restrictions on agricultural land trade; insufficient financial support for farmers; changeability of the financing system, as well as lower and lower supply of state land that could still be afforested [7,41,49,52,53]. The latter is of the greatest importance for the State Forests. The afforestation potential of Poland is estimated to be up to 2 million ha of poor soils which do not guarantee the profitability of agricultural production [48], however, these sites often support habitats of valuable non-forest ecosystems and species.

Forest cover. Efforts undertaken towards augmentation of forest cover in Poland (Figure 2) have resulted in achieving forest cover of $29.6 \%$ (Table 1), against the average of $34.8 \%$ in Europe, which ranks Poland only 27 on the continent, even with ninth largest forest area (excluding Russia) [1]. It should be noted, however, that official Polish statistics on forest land often do not include abandoned agricultural lands, with noticeable forest vegetation [7]. When these were included in statistics, in 2014, Poland's forest cover was $29.4 \%$, while the real forest cover was $32.0 \%$ [7,54]. In view of the above, in Poland, there is a need to classify all lands covered by forests into the category: forest land and to update statistics as regards forest cover $[49,54]$.

Share of forests managed by the State Forests. Although the share of forest area administered by SF declined somewhat over the study period, it is still high, which is characteristic of the former socialist "Eastern Block" countries $[1,7,55]$. In view of Poland's biodiversity conservation (all levels, including the landscape), state ownership of forests/lands constitutes a pillar of nature conservation [56]. 


\subsection{Forest Fragmentation}

The size and location of the forest have an influence on its role in shaping the landscape and determine forest functions associated with supporting ecosystems and providing habitats for species $[57,58]$. The minimum forest size to ensure the protection of forest interior species is $30-40$ ha [59]. However, the best conditions are provided by the core forest area of at least 10,000 ha, covered by continuous forest with a density exceeding $90 \%$. The conditions are also very good, if adjacent forest patches are connected with core forest areas [57].

As estimated, deforestation for agricultural purposes carried out in Poland over many centuries has led not only to the reduction in forest area, but also to its considerable fragmentation [60,61]. Such adverse effects were observed in the socialism era [22]. Due to the lack of SF-only data, Table 2 presents available statistics for all Poland's forests (the vast majority of which is managed by SF-almost 77\% in 2020 [46]). From the perspective of SF, the percentage values presented may be partial as they concern also private forests (just over 19\% [46]), where fragmentation is higher [39]. The data presented below (Table 2), reflecting the situation in 21st century (democracy era), were compiled consistent with a uniform methodology.

Table 2. Fragmentation of Polish forests *.

\begin{tabular}{|c|c|c|c|c|c|c|c|c|}
\hline Year & 1950 & 1960 & 1970 & 1980 & 1990 & 2000 & 2010 & $2020^{2}$ \\
\hline $\begin{array}{l}\text { Number of forest patches } \\
\text { [items] }\end{array}$ & n.a. & n.a. & $23,020^{1}$ & n.a. & n.a. & 8666 & n.a. & 8647 \\
\hline $\begin{array}{c}\text { Average forest patch size } \\
\text { [ha] }\end{array}$ & n.a. & n.a. & n.a. & n.a. & n.a. & 1324 & n.a. & 1325 \\
\hline $\begin{array}{c}\text { Separated forest patches } \\
{[\%]}\end{array}$ & n.a. & n.a. & n.a. & n.a. & n.a. & 4.4 & n.a. & 4.5 \\
\hline Continuous forest [\%] & n.a. & n.a. & n.a. & n.a. & n.a. & 95.6 & n.a. & 95.5 \\
\hline $\begin{array}{c}\text { Share of forest patches up } \\
\text { to } 10,000 \text { ha in total forest } \\
\text { area [\%] }\end{array}$ & n.a. & n.a. & n.a. & n.a. & n.a. & 16.3 & n.a. & 16.3 \\
\hline $\begin{array}{l}\text { Share of forest patches } \\
\text { larger than } 10,001 \text { ha [\%] }\end{array}$ & n.a. & n.a. & n.a. & n.a. & n.a. & 83.7 & n.a. & 83.7 \\
\hline
\end{tabular}

Number of forest patches. In the process of economy transition, as said by some available information sources, in the forests exclusively under SF management, there occurred "tens of thousands of forest patches" [22]. In contrast, data for the year 2000 presented in Table 2 (for Poland as a whole) indicate the existence of about 9000 forest patches. This considerable discrepancy stems from not the same methods of classification. The efforts to decrease the number of forest patches undertaken in the course of transition are reflected here only to a small extend, even though the reduction of forest fragmentation through coherent forest stands connected with ecological corridors is one of the most important objectives of the National Program for the Augmentation of Forest Cover [47,49,63]. It is also worth noting, that although the forest area increased by about 400 thousand hectares in 21st century (Table 1), the number of forest patches has somewhat decreased (Table 2), which proves a positive direction of change. Nowadays, however, the implementation of the Program faces many difficulties (Section 3.1), which may impede the process of reducing forest fragmentation in Poland, also in forests managed by SF.

Average forest patch size. A negligible difference between the values of average forest patch size for 2000 and 2018 (Table 2) is somewhat perplexing, especially in view of available data, as it indicates that the total forest area in Poland increased (as said above: by almost 400 thousand ha) and the number of patches slightly decreased (by19 patches). Therefore, for the purpose of this study, own calculations were carried out, with the use of data on the forest area for 2000 (Table 1) and 2018 [30] and data on the number of patches shown in Table 2. The obtained results showed that the average forest patch size was 1023 ha and 1070 ha, for the years 2000 and 2018, respectively. This result better than in 
Table 2 reflects the changes that have occurred during the 18 years of the 21st century. When compared with other European countries (the average forest patch size: $763 \mathrm{ha}$ ), forest patches in Poland's forests are considerably larger, although much smaller than, e.g., those in Sweden (2687 ha), the Netherlands (2880 ha) and Finland (3371 ha) [1]. A slightly increasing trend in Polish forests can be considered positive, contrary to the average negative trend recorded in European forests [1].

Continuous forest vs. separated patches. The establishment of new forests as a result of reforestation/afforestation or natural succession, in the form of isolated patches or irregular branches of already existing forests, enhances forest fragmentation. In particular, this applies to the areas with low forest cover and fragmented forest-ownership structure [39]. In 21st century, an increasing share of smaller, fragmented forest patches has been observed not only in Poland (Table $2-0.1 \%$ ), but also in other European regions, especially in central-west Europe and south-west Europe [1]. When compared to other countries, forest fragmentation in Poland (Table $2-4.5 \%$ ) is still relatively low, which is encouraging-lower values are recorded only in a few countries, e.g., Netherlands (1.3\%), Sweden (1.2\%) and Finland (1.1\%) [1].

Patches of various size. As reported in the SoEF Report [1], the proportions of different size forest patches in total Poland's forest area in 2000 and 2018 (Table 2) are identical, regardless of changes in total forest area as well as in the number of patches. Taking the latter values as correct, the current share of Poland's forests creating the best conditions for forest species preservation [57] is quite high (at a country level-almost $84 \%)$. In the case of SF, this value may be even higher, as privately owned forests show greater fragmentation. The value for Poland is higher than the overall average for Europe $(76.6 \%)$ and lower than that reported by other European countries, e.g., the Netherlands and Sweden (95.5\% each) (based on [1]).

\subsection{Protected Forests}

Focused on safeguarding biological diversity and natural ecological processes, protected areas are one of the oldest tools for the protection of the world's nature and natural resources [1]. They considerably contribute to the landscape values, and in the case of forests can be visually distinguished-in protected forests, there are relatively fewer (or not at all) noticeable traces of cutting/logging which usually result in a decrease of landscape aesthetic and recreational values [64]. Some protected areas had been established within the area of today's Poland before the country regained its independence (before 1918, e.g., nature reserves established in Nawojowa, southern Poland or near Lesko, south-eastern Poland) [65,66], nonetheless, the system of nature protection (including establishment of protected areas) was gradually reorganized in the decades after the year 1945 [65,67]. Since then, nature (forest) protection has undergone qualitative and quantitative development (Table 3).

Table 3. Area of protected forests (PL-Poland, SF-State Forests) *

\begin{tabular}{|c|c|c|c|c|c|c|c|c|c|}
\hline Year & PL/SF & 1950 & 1960 & 1970 & 1980 & 1990 & 2000 & 2010 & 2020 \\
\hline National parks & PL & 10.5 & 55.9 & 66.9 & 82.9 & 118.8 & 190.9 & 194.7 & 195.2 \\
\hline [thousand ha] & $\mathrm{SF}$ & - & - & - & - & - & - & - & - \\
\hline \multirow{2}{*}{$\begin{array}{l}\text { Nature reserves } \\
\text { [thousand ha] }\end{array}$} & PL & 0.02 & 16.3 & $>10.4^{1}$ & $>16.7^{1}$ & $>35.9^{1}$ & 84.2 & 99.2 & 117.8 \\
\hline & $\mathrm{SF}$ & 0.02 & n.a. & $28.3^{2}$ & $25.4^{3}$ & 42.6 & 66.0 & 88.9 & 104.5 \\
\hline \multirow{2}{*}{$\begin{array}{l}\text { Landscape parks } \\
\text { [thousand ha] }\end{array}$} & PL & - & - & - & 109.8 & 687.7 & 1345.9 & $>1421.1^{4}$ & 1446.9 \\
\hline & $\mathrm{SF}$ & - & - & - & n.a. & n.a. & n.a. & $1137.0^{5}$ & $1256.7^{6}$ \\
\hline \multirow{2}{*}{$\begin{array}{l}\text { Landscape protection } \\
\text { areas [thousand ha] }\end{array}$} & PL & - & - & - & 283.4 & 2113.8 & 2856.5 & $>2227.9$ & 2942.3 \\
\hline & $\mathrm{SF}$ & - & - & - & n.a. & n.a. & n.a. & $2244.6^{5}$ & $2467.6^{6}$ \\
\hline \multirow{2}{*}{$\begin{array}{l}\text { Natura } 2000 \text { network } \\
\text { [thousand ha] }\end{array}$} & PL & - & - & - & - & - & - & $2767.8^{4}$ & 3243.8 \\
\hline & $\mathrm{SF}$ & - & - & - & - & - & - & $2780^{7}$ & $2888^{7}$ \\
\hline
\end{tabular}

* sources: $[4,7,32-34,36,43,45,48,62,67-74] ;{ }^{1}$ data for forest reserves only; ${ }^{2}$ data for $1969 ;{ }^{3}$ data for $1982 ;{ }^{4}$ data for $2011 ;{ }^{5}$ data for 2008 ;

${ }^{6}$ data for 2018; ${ }^{7}$ non-forest areas included; "-" —fform of protection does not exist, n.a.—information not available. 
Dynamics of change of protected forest area. During the whole study period, the area of protected forests in Poland (excluding Natura 2000) increased from 0 ha (start of implementation of a new approach towards nature conservation, after 1945) to 4702.2 thousand ha (calculated on the basis of Table 3). Currently it accounts for $50.8 \%$ of the total forest area. In the years 1945-1990 (the socialism era), an increase of protected forest area amounted to more than 2956.2 thousand ha (on average more than 65.7 thousand ha/year), whereas in the years 1990-2020 (the democracy era) - the increase was less than 1746 thousand ha (on average less than 58.2 thousand ha/year). Not counting Natura 2000 sites, the average increase in the protected area in the two studied time intervals (socialism and democracy eras) was most likely equal. It should be stressed, however, that in the socialism era, the expansion of nature protection areas in forests was running rather irregularly, as until the early 1980s, it was relatively slow (Table 3). By then, approximately $5.7 \%$ of the area of Polish forests was protected. A significant increase in the area of protected forests was observed in the last decade of the socialism era (1980-1989/90) and the first decade of the democracy era (1990s). This was a period of dynamic political, economic, and social changes that resulted in acknowledgement of the importance of environmental protection. The second stimulus for the development of forest protection-already in the democracy era-was Poland's accession to the EU and the need to implement the Natura 2000 network. The established Natura 2000 sites partly overlap with other forms of nature protection in Poland (Figure 3), thus, in the final analysis, they did not significantly affect the expansion of protected forest area as much as actions undertaken already in the 1980s and 1990s.

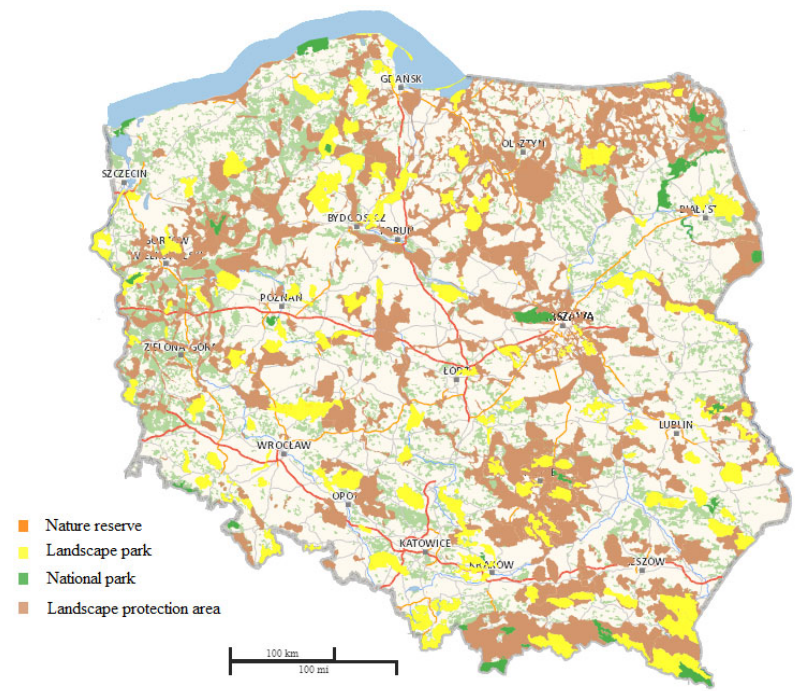

(a)

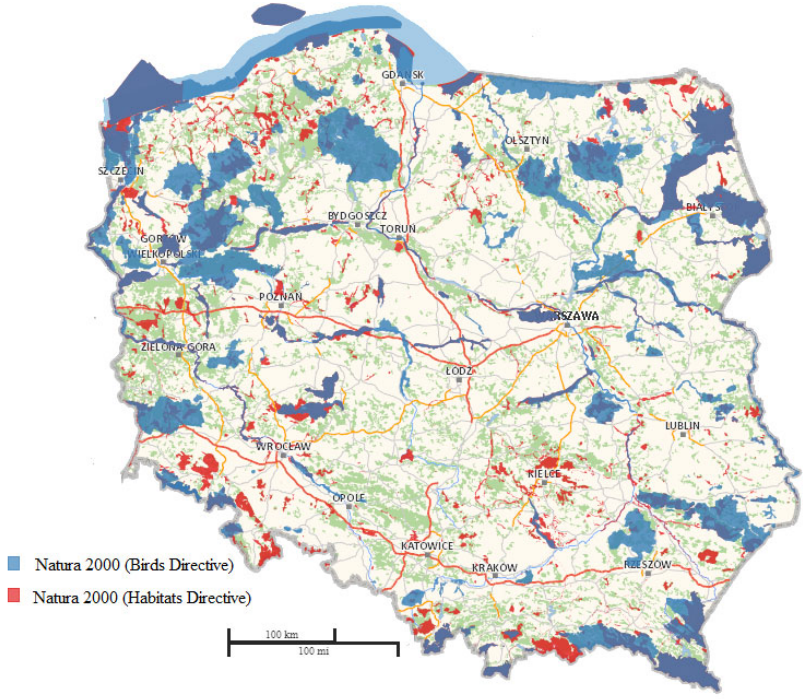

(b)

Figure 3. (a) Distribution of protected areas (national parks, nature reserves, landscape parks and landscape protection areas) in Poland (2021); (b) Distribution of Natura 2000 areas in Poland (2021) (based on [75]).

Contribution of SF to nature conservation. The majority of Poland's protected areas (excluding national parks) and objects are situated in forests under management of the State Forests (Table 3). At the beginning of 2019, in total 70.6\% of the forests managed by SF were under different types of protection [56]. These were predominantly forested areas; however, there were also protected non-forest areas in spatial arrangements with forest areas (e.g., peatlands, water courses and reservoirs, heathlands). The protected areas and objects of protection were gradually designated in SF managed forests throughout the whole period under the study (Table 3), however, only in the democracy era, the spectrum of foresters' activities in this respect was considerably broadened. Since 1998, the nature conservation program comprising information about the protected areas and objects has been a mandatory part of the forest management plan for each forest district $[21,26]$. Additionally, in many SF units, there were carried out trainings on nature conservation 
(with special emphasis put on Natura 2000 [76]). On the one hand, this new approach resulted from the increased capacity of foresters and recognition of the necessity to protect forest biodiversity (at all levels, including landscape), and on the other-from public pressure. As in other European countries, in Poland, there has been observed the socalled paradigm shift in nature protection [77]. Consequently, there prevails the preference of Polish society for socio-cultural and ecological functions of public forests as well as assurance of favorable conditions for well-being of forest ecosystems and species [26,78].

FOREST EUROPE classes of protected forests. FOREST EUROPE distinguishes several classes of protected forests: Class 1 -protection of biodiversity (Class 1.1-no active intervention, Class 1.2-human intervention limited to minimum, Class 1.3-conservation through active management) and Class 2-protection of landscapes and specific natural elements [1]. Table 4 summarizes data on Polish forests in the democracy era [1], supplemented by own calculations for the socialism era (according to the methodology adopted in Poland for SoEF [1]). The latter-due to scarce information-are approximate.

Table 4. Protected forests (FOREST EUROPE Classes) in Poland *.

\begin{tabular}{ccccccccc}
\hline Year & $\mathbf{1 9 5 0}$ & $\mathbf{1 9 6 0}$ & $\mathbf{1 9 7 0}$ & $\mathbf{1 9 8 0}$ & $\mathbf{1 9 9 0}$ & $\mathbf{2 0 0 0}$ & $\mathbf{2 0 1 0}$ & $\mathbf{2 0 2 0}$ \\
\hline Class 1.1 [thousand ha] & 6.8 & $<29.6$ & $<25.8$ & 22.7 & 30.4 & 51.3 & 55.6 & 72.4 \\
Class 1.2 [thousand ha] & - & - & - & - & - & - & - & - \\
Class 1.3 [thousand ha] & 3.6 & $<58.9$ & $>61.8$ & 76.9 & 150.8 & 226.3 & 243.8 & 3019.7 \\
Class 2 [thousand ha] & - & - & - & 109.8 & 687.7 & 1346 & 1308 & 457.2 \\
\hline * Sources: [1,19,68,69,79]." "- form of protection does not exist.
\end{tabular}

*Sources: [1,19,68,69,79]; "-"-form of protection does not exist.

A considerable discrepancy between data for Class 1.3 and Class 2 in the year 2020 compared to 2010 is a result of counting forests within Natura 2000 sites in Class 1.3, and excluding from Class 2 forests in landscape parks, where Natura 2000 sites are also present. Currently, on the scale of Europe as a whole, about $24 \%$ of reporting countries' forests are protected areas designated for the protection of biodiversity (15\%) or landscape and specific natural elements (9\%) [1]. In the case of Poland, these areas constitute 33\% and 5\%, respectively (calculated on the basis of Tables 1 and 4). The high share of Class 1 forests, which ranks Poland 3 in Europe (next to the Republic of Moldova and Italy), is almost entirely due to the dominance of Class 1.3 forests. The area of Class 1.1 forests is very small-countries with similar total forest area to Poland have much more forests with no active intervention, in Italy these grow on 270 thousand ha, and in Ukraine-on 293 thousand ha. The share of Class 2 forests in Poland is lower than Europe's average, and in relation to the countries with similar forest area it is higher than in Ukraine, and lower than in Italy [1]. From the point of view of the protection of forest landscapes, Class 1.1 and Class 2 forests are particularly important.

\subsection{Protective Forests}

Maintaining forests is a condition for, among others, preserving and regulating water relations as well as protecting nature and landscape $[6,7,48]$. In this respect some forests play a vital role, therefore, in their case, the protective functions should have higher priority than those productive.

After the World War II, starting from 1957, protective forests were designated in Poland, under six categories, including landscape forests. Over the years, the latter category was step by step neglected [80]. Currently, 10 categories of protective forests are designated $[21,81]$. Of these, forests designated for the protection of water or those safeguarding natural values, as well as animal refugees are of particular importance for biodiversity conservation (Table 5). The higher priority of the conservation function than the production function has in this case a positive influence on the protection of landscape values. 
Table 5. The area of selected categories of protective forests in SF *.

\begin{tabular}{|c|c|c|c|c|c|c|c|c|}
\hline Year & 1950 & 1960 & 1970 & 1980 & 1990 & 2000 & 2010 & 2020 \\
\hline Water conservation forests [thousand ha] & - & n.a. & $205.7^{1}$ & 240.2 & 559.6 & 1231.8 & 1490.5 & 1552.3 \\
\hline Landscape forests [thousand ha] & - & n.a. & $637.1^{1}$ & 705.2 & 654.3 & 66.6 & - & - \\
\hline Valuable natural forests [thousand ha] & - & - & - & - & - & 44.7 & 139.7 & 577.1 \\
\hline Animal refuges [thousand ha] & - & - & - & - & - & 67.2 & 73.8 & 64.1 \\
\hline $\begin{array}{c}\text { Total area of the analyzed protective forests } \\
\text { [thousand ha] }\end{array}$ & - & n.a. & 842.8 & 945.4 & 1213.9 & 1410.3 & 1704.0 & 2193.5 \\
\hline
\end{tabular}

* sources: [19,33-36,43,82]; ${ }^{1}$ data for 1975; "-"—form of protection does not exist, n.a.-information not available.

Dynamics of change of protective forest area. During the studied period, the area of the analyzed protective forests increased from 0 ha to 2193.5 thousand ha (Table 5). Currently it amounts to about $30.8 \%$ of forest area under SF management. In the socialism era, starting from 1957, protective forest area increased to 1213.9 thousand ha (on average 36.8 thousand ha/year), whereas in the period of democracy, the increase was 979.6 thousand ha (on average 32.7 thousand ha/year). The lower increase rate in the democracy era can be explained by reduced possibilities for designation of additional protective forests, considering absence of a rationale for special protection of some other forests, and a need for keeping the balance between ecological and economic functions of forests (in view of SF self-financing).

Water conservation forests. Forest areas designated to protect surface- and groundwater resources and to regulate hydrological relations in catchment and watershed areas are established in Poland compliant with the Forest Act [21]. Their specific landscape is vulnerable to environmental changes, and especially those connected with water relations. In Poland, numerous valuable forests in terms of water conservation have been degraded as a result of land reclamation (drainage), which was realized until the end of the socialism era [83], even though the protection of exceptional biodiversity of wet forests was already advocated in the 1970s [84]. The protection of wet forest habitats in the form of water-conservation forests began in the socialism era (with greater intensity at the end of this period), however, appropriately intense activities in this regard were undertaken only in the democracy era (Table 5). This resulted from: changes in the forest management model towards ecological dimension; the objectives of biodiversity conservation at a global level [85]; factual implementation of the Ramsar Convention [86]; active participation of Poland in the processes of the Ministerial Conference on the Protection of Forests in Europe (FOREST EUROPE) [55] as well as a recognized need to take into account climate change effects (e.g., periodic droughts [87]).

Animal refuges. This protection form was introduced after 1990 (the democracy era) to safeguard habitats of particular importance for animals under species protection [81], as well as those associated with species/gene pool protection [88]. The trend of changes of animal refuge areas over time does not seem explicit, and has been somewhat decreasing in the last decade (Table 5). This may be due to the fact that concurrently there also exists an analogous (more restrictive) form of nature conservation (selected species protection zones, compliant with Nature Conservation Act [89]) existing since the 1983 and gradually covering more and more taxa. At the end of 2020, in state-owned forests managed by SF, there were designated in total 3990 animal protection zones (an area of 163,000 ha) [46]. These probably fulfilled to some extent the need to designate more animal refuges.

Valuable natural forests. This category of forests was acknowledged after 1990, and defined as valuable fragments of native wildlife [81]. They initially safeguarded valuable/protected plant species and rare/rich/endangered forest ecosystems. Ecosystem services provided relate to the protection of habitats and species/gene pool [88]. Over time, forest of this kind were included into the system of forest management certification by the Forest Stewardship Council (selected categories of High Conservation Values Forests [90]). The area of valuable natural forests significantly increased along with the progress of FSC 
certification in Poland's forests (by now, FSC certificate has been granted to approx. to $97.7 \%$ forests under SF management [91]).

Landscape forests. In the era of socialism, selected forests were designated to protect forest aesthetic and landscape values. Starting from the 1970s, gradual withdrawal of this form of protection coincided with creation of landscape parks (Section 3.3), which by definition protect natural landscapes [89], especially those associated with forests [30]. Thus, it can be considered that this form of nature conservation has, in a way, taken over the function of former protective forests. At the same time, since the beginning of the democracy era, the protection of forests particularly valuable due to their landscape values has been declared in the objectives of Polish forestry [21], which, however, does not entail a separate category of protective forests.

Forest management in protective forests. From the beginning of its functioning in the socialism era, the protective forests were subject to a special management method with positive effects on their landscape values, i.e., clear-cutting was limited, and compound felling with a longer recovery period was recommended; by-product harvesting was limited; water reclamation was restricted; attention was paid to the landscape-forming function of forests [80]. After the political system change, management in protective forests still remained specific, focused on silviculture and protection rather than production [81,92]. This meant, for example, limiting clear-cutting, increasing the age of stands for felling, limiting harvesting of timber and non-timber products $[7,48,81]$ and led to the perception of protective forests as a more restrictive form of nature conservation than, for example, landscape parks [80]. The abovementioned specific management rules in protective forests (applied from the beginning of their functioning) have shaped them somewhat differently as compared to those managed mainly for economic purposes. At the beginning of 2020, the average growing stock density in water conservation forests was $278 \mathrm{~m}^{3} / \mathrm{ha}$, in valuable natural forests $-285 \mathrm{~m}^{3} / \mathrm{ha}$, and in animal refuges- $302 \mathrm{~m}^{3} /$ ha, whereas in non-protective forests it amounted to $259 \mathrm{~m}^{3} / \mathrm{ha}$. At the same time, the proportion of the areas covered by over 80 -year-old stands in the above specified protective forests were $23.8 \%, 28.2 \%$, and $33.9 \%$, respectively, and in non-protective forests-20.8\% (calculated on the basis of [32]). These exemplary parameters and their values show that the structure of protective forests is richer as compared to non-protective forests, and their value for biodiversity conservation is higher. In view of the above, an increase in the protective properties of the protective forests analyzed is clearly visible.

Protective forests in Poland and in Europe. The current share of protective forests in Poland, protecting soil, water, and other forest ecosystem functions (Indicator 5.1 [28]), is quite high (34.6\%). Among countries with available data, a higher proportion of such forests occurs in Romania (39.0\%), Turkey (39.6\%), Moldova (57.4\%), Italy $(87.5 \%)$, and Georgia (100.0\%) (based on SoEF [1]). Yet, from the point of view of biodiversity protection, not all protective forests have a similarly high value. It is also worth noting that protective functions are often integrated into multifunctional forestry [1] and the function such as biodiversity conservation can be realized even without designating protective forests.

\subsection{Harvesting Intensity}

Timber harvesting directly affects forest landscape, on the one hand-through its form (in the extreme case: clear-cutting vs. selection cutting, resulting in two spatially different forest ecosystems [93]), on the other-through harvesting intensity. The intensity/volume of harvesting is planned in relation to growing stock. The change in growing stock in terms of its total amount and per ha of area can be used in the assessment of forest management quality with regard to its impact on forest resources and indirect effects on forest landscape values (e.g., a forest with rich spatial structure vs. forest heavily thinned or composed mainly of young trees). In 1945, in state-owned forests managed by SF, the volume of gross timber amounted to 695 million $\mathrm{m}^{3}\left(129 \mathrm{~m}^{3} / \mathrm{ha}\right)[19,30]$. The following subsequent changes in these parameters-under forest use conditions-are shown in Table 6. 
Table 6. Characteristics of wood resources of SF and their use *.

\begin{tabular}{ccccccccc}
\hline Year & $\mathbf{1 9 5 0}$ & $\mathbf{1 9 6 0}$ & $\mathbf{1 9 7 0}$ & $\mathbf{1 9 8 0}$ & $\mathbf{1 9 9 0}$ & $\mathbf{2 0 0 0}$ & $\mathbf{2 0 1 0}$ & $\mathbf{2 0 2 0}$ \\
\hline Total growing stock [million $\mathrm{m}^{3}$ ] & 735 & 819 & 941 & 1087 & 1280 & 1480 & 1886 & 2067 \\
$\quad$ Harvesting [thousand $\mathrm{m}^{3}$ ] & 14,531 & 18,040 & 19,814 & 20,738 & 16,947 & 25,718 & 33,769 & 38,232 \\
Relation of timber harvest to annual & 51.6 & 57.7 & 74.6 & 50.5 & 49.9 & 58.7 & 61.7 & $73.6^{1}$ \\
increment [\%] & 128 & 133 & 145 & 162 & 188 & 213 & 267 & 290 \\
Average growing stock density [m ${ }^{3} / \mathrm{ha}$ ] & 128 & & &
\end{tabular}

* sources: [4,19,44-46,68,82]. ${ }^{1}$ data for 2019.

Harvest volume. Since the beginning of the period under the study, an increase in the volume of timber harvesting has been observed, with one exception in 1990. The intensified crisis in the development of the country at the end of the socialism era caused a collapse in the timber market at that time [12]. Not only in Poland, but also in the entire region of Eastern Europe, with socialism collapse, the wood industry had to be restructured, which resulted in less logging [12,94]. At the same time, the model of forest management and logging was elaborated, which could ensure economic efficiency [18] and guarantee sustainable management of wood resources $[18,95,96]$, so as to maintain forest landscape quality. It should be emphasized that even during the socialism era in Poland, there was harvested no more wood than its annual increment [19,30], in contrast to e.g., the Carpathian part of Ukraine [97]. Nevertheless, in 1947-1956, an increase in harvesting was very rapid, based on not fully justified top-down indicators [12,98].

Dynamics of change in timber resources. In 2020, timber resources (total growing stock) in SF were three times larger than in 1945. Their state at the end of the socialism era was about $180 \%$ of the initial state (average annual growth of about $1.8 \%$ ), while in the democracy era-so far-it has been about 160\% (average annual growth of about $1.5 \%$ ). The decrease of the average growth of the resources with time is caused by the increase of the share of older stands with lower growth rate (based on [36]). Thus, as can be seen, timber resources in SF have grown regardless of increasing timber harvesting, which is due to large-scale post-war afforestation (Section 3.1) and the aforementioned rational harvesting $[18,26]$. This results from the fact that in the socialism era an average of $62.8 \%$ of annual increment was harvested (based on [19]), while in the democracy era an average of $60.3 \%$ was harvested (based on [30]). This parameter in the last two decades was lower than the average in Europe-in the years 1999-2019, harvesting in the State Forests amounted to $63 \%$ (according to [7]), while in Europe-73\% [1]. Thus, despite ranking ninth in Europe (excluding Russia) in terms of forest area, Poland ranks fourth in terms of growing stock [1]. This may indicate the richness and complexity of forest landscapes.

Dynamics of change in average growing stock density. In 2020, the volume of forest stands resources per 1 ha under SF management was more than twice greater $(225 \%)$ than that recorded in 1945. Stand volume at the end of socialism era was $146 \%$ of that in 1945 (average annual increase by 1.0\%) and currently, it is 154\% of that at the beginning of the democracy era (average annual increase by $1.8 \%$ ). This was mainly influenced by the increase in the proportion of older age classes of stands (based on [36]), with dominant specimens of mature, thick trees, significantly increasing the landscape value of the forests [99]. The current average growing stock density under SF management $\left(290 \mathrm{~m}^{3}\right.$ /ha-Table 6) is much higher than that average of European forests $\left(169 \mathrm{~m}^{3} /\right.$ ha [1]).

Harvesting mode. In 2020, only $20 \%$ of all harvested wood came from clear-cutting [46]. In comparison, in the marketing year 1957/1958 (socialism era), this share was $62 \%$ (based on [68]). In view of the landscape values, clear-cuts are negatively perceived by the society [99], hence, their decreasing share in the democracy era can be considered a positive phenomenon. After the change of Poland's political system, as well as the transition of "old" forest management model into pro-environmental, there started to be implemented environmentally friendly technologies, e.g., the use of organic oils in machinery [76]. However, such technologies are in use not always and not everywhere, due to very high costs of their application [100]. 


\subsection{Issues and Directions of the Protection of Forest Landscape in Poland}

Form of forest ownership. One of the threats to the forest landscape (and forest, as well) is a proposal, recurring from time to time, to use a part of the State Forests for the restitution of private property (forest and non-forest) - nationalized after the World War II. Forests are a significant component of state property, and in a way they represent a natural candidate for restitution purposes [18]. At the same time, private forests are subject to less demanding regulations as regards biodiversity conservation than those imposed on stateowned forests [21]. Even though since 2001, the state forests have been acknowledged as a national resource that should be preserved [101], legislation can be changed any time. For this reason, it has been postulated that provisions as regard national character of Poland's forests should be included in Poland's Constitution, which has not yet been realized. It would be worth returning to this issue.

Functioning of the State Forests. The State Forests National Forest Holding manages the vast majority of the country's timber resources [30], which arouses the interest of Polish politicians. Proposals are being formulated to include SF finances in the public finance sector, as well as to change the legal formula of SF functioning [78]. Meanwhile, the change of, for example, financial management in SF may result in the change of forest management priorities (e.g., towards boosting a production function) and, in turn, in the deterioration of biodiversity, including landscape diversity. Therefore, the current formula of SF functioning should be maintained.

Forest Policy. The National Forest Policy, adopted in 1997, has no reference to several recent commitments of Poland under the FOREST EUROPE process (e.g., the resolution "Conserving and Enhancing Forest Biological Diversity in Europe") [23], as well as those associated with the accession to the EU (e.g., the Natura 2000 Network, which protects specific habitats/landscapes of particular biogeographical regions, including forests). Although these contents are reflected in the documents organizing the functioning of the State Forests, the lack of a nationwide, up-to-date policy should be considered as negative factor in view of, among others, the protection of forest landscapes. Attempts made in 20th century to create a National Forest Program have not resulted in its legal establishment. This problem should be solved as soon as possible.

Extreme weather events. The presence of forest landscapes can be threatened by extreme events due to climate change, such as catastrophic storms $[17,87,102]$, which haunted Sweden and Central Europe in the past decade [1,31]. A large storm that passed over Poland on 11 August 2017 toppled or broke about 25 million trees in the northwestern part of the country [31]. In 2019, wind damage occurred on 42,300 hectares of forests (in 2020 - on 10,700 hectares), being one of the two most important damages from abiotic factors [7,46]. Poland's main forest-forming species, Scots pine (Pinus sylvestris), is particularly vulnerable to strong winds [103]. In addition to the destruction of the forest landscape, the extreme weather events cause high financial losses, including lower income from the sale of poorer quality timber. Therefore, the selection of planted tree species in consideration of their resistance to extreme weather events should be of particular importance.

Droughts. Under Poland's conditions, periods of rainfall shortage due to climate change occur more and more frequently $[7,87]$. Drought threatens forests directly, as water deficiency can lead to death of trees, and indirectly-as it increases a risk of wildfires. Both factors have detrimental effects on the forest landscape. For example, in the very dry year 2015, there broke out 3897 fires in state-owned forests managed by the SF, more than twice many when compared to the year with high precipitation, i.e., 2010 (1777 forest fires recorded) $[7,30]$. Due to the high risk of fires, affecting over $80 \%$ of forest area in Poland, the fire protection system has been developed since 1945 [7,87,104]. As a result, the number of fires and the average area of a single fire have been gradually decreasing over the last 20-30 years, which is a good prognosis in the context of climate change [104]. This trend is worth maintaining. On the contrary, damage and death of tree stands due to drought shows an increasing trend. In 2020, of all the abiotic negative factors, the impact of extreme drought was the most detrimental, and tree stand damages were reported on 
nearly 62,500 hectares [46]. In response to this problem, since the 1990s, in forests managed by the SF, there have been carried out activities to restore small-scale retention [7,87], disrupted by land melioration implemented almost until the end of the socialism era [83]. In view of the forest landscape conservation needs (also those of habitats and species), it is important to continue retention work in all forest areas where it is possible and needed.

Organizational problems of forest landscape protection. The increase of the legally protected area in forests (Section 3.3) is important in view of benefits for biodiversity [1]. Vegetation in unmanaged and protected forests is more resilient to environmental changes and characteristic of large spatial diversity [105], which translates into the landscape values. On the other hand, however, if protected areas are accumulated within lands administered by a single entity, such as the State Forests, which is the case of Poland, they may pose a number of organizational challenges. Setting out conservation rules and allocation of responsibilities for protected areas designated in state-owned forests managed by SF have been a part of a complex process carried out under the conditions of duties dispersed among various external entities [56]. Another challenge which SF administration has to face concerns approaches taken and communication, for example during development of management plans for Natura 2000 sites The approach assumed by foresters is hardly ever accepted by environmental NGOs, who as a rule demand robust protection of discussed Natura 2000 sites [77], regardless of the fact that, by definition, contemporary nature protection must take into consideration not only ecological dimension, but also those economic and social as well as regional and local circumstances [26].

Financial problems of forest landscape protection. The increase of the protected area in forests (protected forests and protective forests) is also important from the financial perspective. In protected/protective forests, the ability to use their productive function is limited $[78,81,89]$. At the beginning of 2020, more than 1.25 million hectares of SF managed forests were partially excluded from timber harvesting (17.6\% of SF area), and at least 530,000 hectares $(7.5 \%)$ of this area was fully excluded from harvesting [31]. An increased area of protected sites translates into a decreased area of commercial forests [78] - the main source of income for the State Forests (e.g., [31,106]). The reduction in forest production efficiency, and consequently, lower income can lead to a decline of biodiversity conservation activities carried out by the State Forest [18]. Indeed, it should be emphasized that the direct costs of nature conservation incurred by SF have been still increasing, e.g., in 2009 they amounted to 4.8 million PLN [107], and in 2019-15.3 million PLN [31]. Additionally, since 2012, the State Forests have financially supported national parks (annually 20-50 million PLN [31,106,108-112]). Meanwhile, since 2009, the State Forests have received no targeted subsidies from the state budget for nature protection, even though the law allows such support [56,74]. In the case of protective forests, until 2015, forest management restrictions were compensated by half the forest tax rate, and now they are not [80]. Currently, the area of protective forests constitutes $53.6 \%$ of forests under SF management [7], and many of these areas have an analogous rank and function to protected areas designated under the Nature Conservation Act [89]. The above described circumstances pose a financial challenge for the State Forests, given that SF is a self-financing organization [21,26]. In order to resolve these problems, different solutions have been advocated, such as looking for additional financial sources for nature conservation [56], including restoration of subsidies from the state budget to the State Forests [21]. Another solution proposed is to reduce areas under strict protection (in fact, the state of nature is good even in economically used forests) or else to decrease the costs of forest nature conservation [41]. The most important issue is to find a proper balance between conservation of nature perceived as the national heritage and the rules of economy [26]. In addition, it is important to recognize that public expectations on forest nature conservation are high [74]. This is mainly related to much increased public awareness on environmental threats, which has been influenced by increased access to information (the effect of implementation of the Aarhus Convention [27]) and enhanced public knowledge on environmental issues. 
Distribution and fragmentation of forests. An increase in the total area of forests in Poland (state- and privately owned forests) has not translated into an increase in uniformity of forest spatial distribution. The forest cover in administration units (a voivodeship level) varies from $21.4 \%$ to $49.3 \%$ (Figure 4 ): the highest is in the western, northern, and southeastern parts of Poland, the lowest-in the central and eastern parts. In the latter regions, the share of state-owned forests (under SF management) in total forest area is relatively smaller [46].

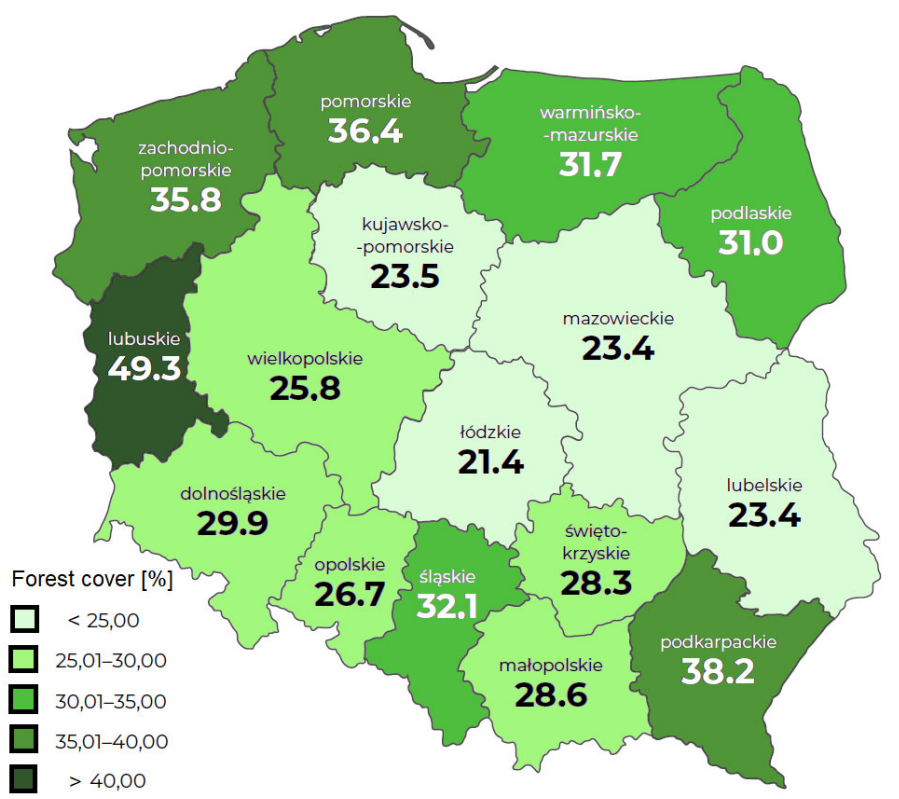

Figure 4. Forest cover of voivodships in Poland (2020) (source: [46], modified).

Low forest cover should therefore be a priority indication for further afforestation. This is because it has been assessed that the uneven distribution of forests, as well as their fragmentation, are one of the reasons for deterioration of ecological coherence in the spatial management of Poland [113]. Even though Raši and Schwarz [114] state that the interpretation of forest fragmentation impact on biodiversity remains limited, the authors of several studies consider fragmentation as one of the most radical disturbances for forests and show explicitly its negative effects [58]. At the landscape level, fragmentation can reduce carbon storage [58,115] and aggravate negative effects of other disturbances and hazards [116,117]in extreme situations leading to degradation/destruction of forest patch/ecosystem. Forest fragmentation threatens biodiversity also at a species level (especially interior forest species) and can considerably hinder dispersal of specimens [57,58,118,119]. At the same time, it affects genetic biodiversity by causing genetic isolation, weakening genetic diversity, and limiting responses to multiple stresses [57,58,120]. For the above reasons, it is advisable to decrease forest fragmentation. Another factor that worsens ecological coherence is the legislation that, since 2003, has made it easier to cut down state-owned forests to build more roads [26], which is a simpler and cheaper solution than negotiations with private landowners. Improving the situation with regard to forest distribution and fragmentation would require changes in the law and extensive and practical consideration of these issues in land use plans and plans for further afforestation.

Landscape conservation in forest management. Forest landscapes are protected at a national and SF level not only through maintenance of appropriate forest cover, designation of protected areas and protective forests, but also through preservation of specific forest diversity. Since 1952, there has been functioning periodically improved natural-forest regionalization, which since 1990 (after the change of political system) has also taken into account ecological conditions of vegetation development. Currently, 183 mesoregions (which can be assumed as types of forest landscapes) are distinguished all through Poland 
(including SF) based on geological criteria; landscape types; landforms; climatic conditions; ranges of economically important tree species; and ranges of plant communities [121]. The natural/landscape distinctiveness of landscapes - units higher than mesoregions-has been taken into account in silvicultural principles, especially since 1990, when defining species compositions of stands on particular habitats (this refers to the selection of species and proportions between them [122]).

\section{Conclusions}

On the one hand, the period of 75 years refers to less than the life span of an average forest stand in Poland, and on the other-it is the period of evolution of Polish forestry, which was marked by two very different political and economic eras: socialism and democracy. The transformation influenced the assessed direction and intensity of changes in the forest landscape, although to different extent, depending on the analyzed indicator. In the socialism era, the total forest area, timber resources (total growing stock), as well as the area of protected forests important for biodiversity safeguarding increased more intensively, whereas in the democracy era, there was observed an intensive increase in average growing stock density, as well as there was put a greater emphasis on reducing forest fragmentation and the use of clear-cutting (disadvantageous for the landscape). The average increase in the area of the protected forests was equal in both epochs, although it was most intensive at their junction. The direction of changes throughout the studied period should be assessed as positive for biodiversity conservation, although not without problems and difficult consequences for the State Forests National Forest Holding, both in organizational and financial terms. Maintaining the quantity and quality of forest landscapes in Poland will require further efforts of foresters, and also legal, political and financial solutions at a national level, as well as actions of communities around the world to reduce the causes of global warming and the accompanying severe weather events and drought.

Author Contributions: Conceptualization, E.R.-C. and B.K.; methodology, E.R.-C.; formal analysis, E.R.-C.; investigation, E.R.-C. and B.K.; writing-original draft preparation, E.R.-C.; writing-review and editing, B.K.; visualization, E.R.-C.; project administration, E.R.-C. All authors have read and agreed to the published version of the manuscript.

Funding: This research received no external funding.

Data Availability Statement: Publicly available datasets were analyzed in this study. This data can be found here: [https://stat.gov.pl/obszary-tematyczne/rolnictwo-lesnictwo/lesnictwo] (accessed on 10 November 2021), [https://stat.gov.pl/obszary-tematyczne/srodowisko-energia/srodowisko] (accessed on 30 October 2021), [https:/ /www.bdl.lasy.gov.pl/portal/publikacje] (accessed on 5 November 2021, [https://www.bdl.lasy.gov.pl/portal/tworzenie-zestawienia-ru] (accessed on 5 November 2021).

Acknowledgments: We would like to thank very much Małgorzata Bidłasik (MSc) from the Institute of Environmental Protection-National Research Institute, for her advice and assistance in the development of Figure 2c. Special thanks should be given to the Reviewers of our work for their efforts and valuable comments that greatly helped to improve the manuscript.

Conflicts of Interest: The authors declare no conflict of interest. The funders had no role in the design of the study; in the collection, analyses, or interpretation of data; in the writing of the manuscript, or in the decision to publish the results.

\section{References}

1. Forest Europe. State of Europe's Forests 2020; Ministerial Conference on the Protection of Forests in Europe FOREST EUROPE; Liaison Unit Bratislava: Bratislava, Slovakia, 2020.

2. Van Calster, H.; Baeten, L.; De Schrijver, A.; De Keersmaeker, L.; Rogister, J.E.; Verheyen, K.; Hermy, M. Management Driven Changes (1967-2005) in Soil Acidity and the Understorey Plant Community Following Conversion of a Coppice-with-Standards Forest. For. Ecol. Manag. 2007, 241, 258-271. [CrossRef]

3. Solon, J. Różnorodność Ponadgatunkowa-Krajobrazy [Over-Species Diversity-Landscapes]. In Różnorodność Biologiczna Polski [Biodiversity of Poland]; Andrzejewski, R., Weigle, A., Eds.; NFOŚ: Warsaw, Poland, 2003; pp. 155-159, ISBN 83-85908-75-7. (In Polish) 
4. Broda, J. Dzieje Lasów, Leśnictwa i Drzewnictwa w Polsce [History of Forests, Forestry and Timber Industry in Poland], 1st ed.; ŻabkoPotopowicz, A., Ed.; PWRiL: Warsaw, Poland, 1965. (In Polish)

5. Jażdżewski, K.; Modrzejewski, A. Polityka leśna państwa pruskiego na obecnych ziemiach polskich w latach $1772-1914$ [Forest policy of Prussian state in the contemporary Polish lands in years 1772-1914]. Sylwan 2013, 157, 63-70. [CrossRef]

6. Nienartowicz, A.; Lewandowska-Czarnecka, A.; Ortega, E.; Deptuła, M.; Filbrandt-Czaja, A.; Kownacka, M. Afforestation of Heathlands and Its Influence on the Land Cover, Accumulation of Plant Biomass and Energy Flow in the Landscape: An Example from Zaborski Landscape Park. EQ 2015, 21, 91-99. [CrossRef]

7. Zajączkowski, G.; Jabłoński, M.; Jabłoński, T.; Szmidla, H.; Kowalska, A.; Małachowska, J.; Piwnicki, J. Raport o Stanie Lasów w Polsce 2019 [Report on the Condition of Forests in Poland in 2019]; CILP: Warsaw, Poland, 2020; p. 105. (In Polish)

8. Rykowski, K. Forest Policy Evolution in Poland. J. Sustain. For. 1997, 4, 119-126. [CrossRef]

9. Wegiel, A.; Jaszczak, R.; Rączka, G.; Strzeliński, P.; Sugiero, D.; Wierzbicka, A. An Economic Aspect of Conversion of Scots Pine (Pinus sylvestris L.) Stands in the Polish Lowland. J. For. Sci. 2009, 55, 293-298. [CrossRef]

10. Keeton, W.S.; Crow, S.M. Sustainable Forest Management Alternatives for the Carpathian Mountain Region: Providing a Broad Array of Ecosystem Service. In Ecological Economics and Sustainable Forest Management: Developing a Trans-Disciplinary Approach for the Carpathian Mountains; Soloviy, I., Keeton, W.S., Eds.; Ukrainian National Forestry University Press: Lviv, Ukraine, 2009; pp. 109-127, ISBN 978-966-397-109-0.

11. Dietze, E.; Brykała, D.; Schreuder, L.T.; Jażdżewski, K.; Blarquez, O.; Brauer, A.; Dietze, M.; Obremska, M.; Ott, F.; Pieńczewska, A.; et al. Human-Induced Fire Regime Shifts during 19th Century Industrialization: A Robust Fire Regime Reconstruction Using Northern Polish Lake Sediments. PLoS ONE 2019, 14, e0222011. [CrossRef]

12. Łuczak, M.; Paschalis-Jakubowicz, P. Uwarunkowania rynku drzewnego w Lasach Państwowych w latach 1918-2008 [Determinants of the wood market of the State Forests in the years 1918-2008]. Sylwan 2013, 157, 506-515. [CrossRef]

13. Banach, J.; Skrzyszewska, K.; Skrzyszewski, J. Reforestation in Poland: History, Current Practice and Future Perspectives. Reforesta 2017, 3, 185-195. [CrossRef]

14. Szujecki, A. Lata Wojny i Okupacji [Years of War and Occupation], 1st ed.; Karlikowski, T., Ed.; Z dziejów Lasów Państwowych i leśnictwa polskiego 1924-2004 [The history of the State Forests and the Polish Forestry 1924-2004]; CILP: Warsaw, Poland, 2006; Volume 2, ISBN 83-88478-93-1. (In Polish)

15. Bałtowski, M. Gospodarka Socjalistyczna w Polsce: Geneza—Rozwój—Upadek [The Socialist Economy in Poland: Genesis—DevelopmentDecline], 1st ed.; Wydawnictwo Naukowe PWN: Warsaw, Poland, 2009; ISBN 978-83-01-16044-9. (In Polish)

16. Swadźba, S. System Gospodarczy Polski w Latach 1918-2018 [Poland's Economic System from 1918 to 2018]. Optimum 2019, 1, 19-31. [CrossRef]

17. Mederski, P.; Jakubowski, M.; Karaszewski, Z. The Polish Landscape Changing Due to Forest Policy and Forest Management. iForest 2009, 2, 140-142. [CrossRef]

18. Siry, J.P.; Newman, D.H. A Stochastic Production Frontier Analysis of Polish State Forests. For. Sci. 2001, 47, 526-533. [CrossRef]

19. Rozwałka, Z. Las w Liczbach [Forest in Numbers]; Rozwałka, Z., Ed.; ARW A. Grzegorczyk: Warsaw, Poland, 1997; ISBN 83-8690211-6. (In Polish)

20. Effects of Air Pollution on Forest Health and Biodiversity in Forests of the Carpathian Mountains; Szaro, R.C.; Bytnerowicz, A.; Oszlányi, J.; Godzik, B. (Eds.) NATO Science Series; IOS; Ohmsha: Amsterdam, The Netherlands; Washington, DC, USA; Tokyo, Japan, 2002; ISBN 978-1-58603-258-6. Available online: https: / / books.google.co.jp/books?id=FRz1t6G16I4C\&printsec=frontcover\&dq= Effects+of + Air + Pollution + on + Forest + Health + and + Biodiversity + in + Forests + of + the + Carpathian + Mountains\&hl=zh-TW\&sa $=$ X\&redir_esc=y\#v=onepage\&q=Effects $\% 20$ of $\% 20$ Air $\% 20$ Pollution $\% 20$ on $\% 20$ Forest $\% 20$ Health $\% 20$ and $\% 20$ Biodiversity $\% 20$ in $\%$ 20Forests $\% 20$ of $\% 20$ the $\% 20$ Carpathian\%20Mountains\&f=false (accessed on 11 November 2021).

21. The Forest Act, 1991 [Dz. U. 1991.101.444 as Amended]. Available online: http://isap.sejm.gov.pl/isap.nsf/download.xsp/ WDU19911010444/U/D19910444Lj.pdf (accessed on 4 March 2020). (In Polish)

22. Ministerstwo Ochrony Środowiska, Zasobów Naturalnych i Leśnictwa. In Polityka Leśna Państwa [National Forest Policy]. Document Approved by the [Polish] Council of Ministers on 22 April 1997, 1st ed.; MOŚZNiL: Warsaw, Poland, 1997.

23. Kaliszewski, A.; Gil, W. Cele i priorytety "Polityki leśnej państwa" w świetle porozumień procesu Forest Europe (dawniej MCPFE) [Goals and priorities of the 'National Forest Policy' in the light of the Forest Europe (formerly MCPFE) commitments]. Sylwan 2017, 161, 648-658. [CrossRef]

24. Director-General of the SF Zarządzenie Nr 11 Dyrektora Generalnego Lasów Państwowych z Dnia 14 Lutego 1995 r. w Sprawie Doskonalenia Gospodarki Leśnej Na Podstawach Ekologicznych [Order No. 11 of the Director General of the State Forests of 14 February 1995 on Improving Forest Management on an Ecological Basis]. Signature: ZZ-710-13/95 1995. Available online: https: / / www.wroclaw.lasy.gov.pl/documents /21578137/0/Zarzadzenie+Nr+11.pdf/3b10b05b-1803-46b9-9461-d76d2 bb20c5f (accessed on 10 June 2021). (In Polish)

25. Director-General of the SF Zarzadzenie [Order] Nr 11a Dyrektora Generalnego Lasów Państwowych z Dnia 11 Maja 1999 r., Zmieniające Zarządzenie Nr 11 Dyrektora Generalnego Lasów Państwowych z Dnia 14 Lutego 1995 Roku w Sprawie Doskonalenia Gospodarki Leśnej Na Podstawach Ekologicznych. Signature: ZG -7120-2/99. 1999. Available online: https://www.wroclaw. lasy.gov.pl/documents/21578137/0/Zarz_11A_DGLP_11.05.1999_r.pdf/4edb8ccd-1e91-4166-ae9d-07adc7e1cbf0 (accessed on 25 May 2021). (In Polish) 
26. Czerepko, J.; Geszprych, M.; Gołos, P. Basic Assumptions for Forest Management and Nature Conservation from Axiological, Legal, and Economic Perspective. Folia For. Pol. 2017, 59, 68-78. [CrossRef]

27. Aarhus Convention: Convention on Access to Information, Public Participation in Decision-Making, and Access to Justice in Environmental Matters, Adopted on 25 June 1998 in Aarhus. Polish Version: 2003 [Dz. U. 2003.78.706]. Available online: http:/ / isap.sejm.gov.pl/DetailsServlet?id=WDU20030780706 (accessed on 10 November 2021).

28. MCPFE Updated Pan-European Indicators for Sustainable Forest Management. Annex 1 to Madrid Ministerial Declaration. In Proceedings of the 7th Ministerial Conference, Madrid, Spain, 20-21 October 2015.

29. Forest Europe. SFM Criteria Indicators. Available online: https://foresteurope.org/sfm-criteria-indicators (accessed on 11 November 2021).

30. Leśnictwo [Forestry]. Statistical Yearbook of 2019, 2020. Available online: https://stat.gov.pl/obszary-tematyczne/rocznikistatystyczne/roczniki-statystyczne/rocznik-statystyczny-lesnictwa-2020,13,3.html (accessed on 15 March 2020).

31. Directorate-General of the State Forests. Sprawozdanie Finansowo-Gospodarcze za 2019 rok; Report on Financial and Economic State of State Forests in 2019; DGLP: Warsaw, Poland, 2020; p. 56. (In Polish)

32. BULiGL Bank Danych o Lasach [Forest Data Bank]—A Database on Resources and Condition of Polish Forests. Available online: https: / / www.bdl.lasy.gov.pl (accessed on 11 November 2021).

33. BULiGL Wyniki Aktualizacji Stanu Powierzchni Leśnej i Zasobów Drzewnych w Lasach Państwowych Na Dzień 1 Stycznia 1991 r. [Results of the Update of Forest Area and Timber Resources in the State Forests as of 1 January 1991]. 1991. Available online: https:/ / www.bdl.lasy.gov.pl (accessed on 11 November 2021).

34. BULiGL Wyniki Aktualizacji Stanu Powierzchni Leśnej i Zasobów Drzewnych w Lasach Państwowych Na Dzień 1 Stycznia 2001 r. [Results of the Update of Forest Area and Timber Resources in the State Forests as of 1 January 2001]. 2001. Available online: https:/ / www.bdl.lasy.gov.pl (accessed on 11 November 2021).

35. BULiGL Wyniki Aktualizacji Stanu Powierzchni Leśnej i Zasobów Drzewnych w Lasach Państwowych Na Dzień 1 Stycznia 2011 r. [Results of the Update of Forest Area and Timber Resources in the State Forests as of 1 January 2011]. 2011. Available online: https:/ / www.bdl.lasy.gov.pl (accessed on 11 November 2021).

36. BULiGL Wyniki Aktualizacji Stanu Powierzchni Leśnej i Zasobów Drzewnych w Lasach Państwowych Na Dzień 1 Stycznia 2020 r. [Results of the Update of Forest Area and Timber Resources in the State Forests as of 1 January 2020]. 2021. Available online: https: / / www.bdl.lasy.gov.pl (accessed on 11 November 2021).

37. Kozak, J. Forest Cover Changes and Their Drivers in the Polish Carpathian Mountains since 1800. In Reforesting Landscapes: Linking Pattern and Process; Nagendra, H., Southworth, J., Eds.; Landscape Series; Springer: Dordrecht, The Netherlands; London, UK; New York, NY, USA, 2010; pp. 253-273, ISBN 978-1-4020-9655-6.

38. Sewerniak, P. Survey of Some Attributes of Post-Agricultural Lands in Polish State Forests. EQ 2016, 22, 9-16. [CrossRef]

39. Kozak, J.; Ziółkowska, E.; Vogt, P.; Dobosz, M.; Kaim, D.; Kolecka, N.; Ostafin, K. Forest-Cover Increase Does Not Trigger Forest-Fragmentation Decrease: Case Study from the Polish Carpathians. Sustainability 2018, 10, 1472. [CrossRef]

40. Lawrence, A. Forestry in Transition: Imperial Legacy and Negotiated Expertise in Romania and Poland. For. Policy Econ. 2009, 11, 429-436. [CrossRef]

41. Rozwałka, Z. Leśna Statystyka 1997-2007 [Forestry Statistics 1997-2007]; CILP: Warsaw, Poland, 2010; ISBN 978-83-61633-24-2. (In Polish)

42. Rocznik Statystyczny Leśnictwa i Przemysłu Drzewnego 1964 [Statistical Yearbook of Forestry and Wood Industry 1964]; PWRiL: Warsaw, Poland, 1966. Available online: https:/ / stat.gov.pl/ (accessed on 11 November 2021). (In Polish)

43. Rocznik Statystyczny Leśnictwa i Gospodarki Drewnem 1979 [Statistical Yearbook of Forestry and Wood Economy]; GUS: Warsaw, Poland, 1979. Available online: https:/ / stat.gov.pl/ (accessed on 11 November 2021). (In Polish)

44. Leśnictwo [Forestry]. Statistical Yearbook of 2000; GUS: Warsaw, Poland, 2001. Available online: https://stat.gov.pl/ (accessed on 11 November 2021).

45. Leśnictwo [Forestry]. Statistical Yearbook of 2010; GUS: Warsaw, Poland, 2011. Available online: https://stat.gov.pl/ (accessed on 11 November 2021).

46. Zajączkowski, G.; Jabłoński, M.; Jabłoński, T.; Szmidla, H.; Kowalska, A.; Małachowska, J.; Piwnicki, J. Raport o Stanie Lasów w Polsce 2020; Report on the Condition of Forests in Poland in 2020; CILP: Warsaw, Poland, 2021; p. 162. (In Polish)

47. Forest Research Institute (Poland) Krajowy Program Zwiększania Lesistości [The National Program of the Augmentation of Forest Cover]. 1995. Available online: https://archiwum.mos.gov.pl/fileadmin/user_upload/mos/srodowisko/lesnictwo/ Krajowy_Program_Zwiekszania_Lesistosci.pdf (accessed on 28 November 2021). (In Polish)

48. Forest Research Institute. Raport o Stanie Lasów w Polsce 2010; Report on the Condition of Forests in Poland in 2010; CILP: Warsaw, Poland, 2011.

49. Kaliszewski, A. Krajowy Program Zwiększania Lesistości-Stan i Trudności Realizacji z Perspektywy Lokalnej [National Program for Expanding of Forest Cover-Implementation and Its Difficulties from a Local View]. Studia I Mater. Cent. Edukac. Przyr. Leśnej 2016, 49B, 7-19.

50. Wageningen University and Research The HIstoric Land Dynamics Assessment (HILDA). Available online: https: / / www.wur.nl/en/Research-Results/Chair-groups/Environmental-Sciences/Laboratory-of-Geo-information-Scienceand-Remote-Sensing/Models/Hilda.htm (accessed on 24 November 2021). 
51. IGiK CORINE Land Cover 2018-A Database on Types of Land Cover in Poland. Project Financed by the European Union. Available online: https:/ /clc.gios.gov.pl/index.php/geoportal (accessed on 11 November 2021).

52. Kaliszewski, A.; Młynarski, W.; Gołos, P. Prospects for Agricultural Lands Afforestation in Poland until 2020. Folia For. Pol. 2016, 58, 163-169. [CrossRef]

53. Kurowska, K.; Kryszk, H. Opłacalność zalesień gruntów rolnych w ramach Programu Rozwoju Obszarów Wiejskich [Profitability of the farmland afforestation within the Rural Development Programme]. Sylwan 2017, 161, 1035-1045. [CrossRef]

54. Hościło, A.; Mirończuk, A.; Lewandowska, A. Określenie rzeczywistej powierzchni lasów w Polsce na podstawie dostępnych danych przestrzennych [Determination of the actual forest area in Poland based on the available spatial datasets]. Sylwan 2016, 160, 627-634. [CrossRef]

55. Zając, S.; Kaliszewski, A.; Młynarski, W. Forests and Forestry in Poland and Other EU Countries. Folia For. Pol. 2014, 56, 185-193. [CrossRef]

56. Referowska-Chodak, E. The Organization of Nature Conservation in State-Owned Forests in Poland and Expectations of Polish Stakeholders. Forests 2020, 11, 796. [CrossRef]

57. Kapos, V.; Lysenko, I.; Lesslie, R. Assessing Forest Integrity and Naturalness in Relation to Biodiversity. Forest Resources Assessment Programme, Working Paper 54; Forestry Department FAO: Rome, Italy, 2002.

58. Thompson, I.D.; Guariguata, M.R.; Okabe, K.; Bahamondez, C.; Nasi, R.; Heymell, V.; Sabogal, C. An Operational Framework for Defining and Monitoring Forest Degradation. Ecol. Soc. 2013, 18, 20. [CrossRef]

59. Hladnik, D.; Pirnat, J. Urban Forestry—Linking Naturalness and Amenity: The Case of Ljubljana, Slovenia. Urban. For. Urban. Green. 2011, 10, 105-112. [CrossRef]

60. Ochrona Środowiska w Gospodarce Przestrzennej, 1st ed.; Ryszkowski, L.; Kędziora, A. (Eds.) ZBŚRiL PAN: Poznań, Poland, 2005. Available online: https:// zbkiks.ug.edu.pl/downloads/2012/jc/gp_pugp-materialy-4-system_i_formy_ochrony_srodowiska. pdf (accessed on 11 November 2021)ISBN 83-89887-26-6. (In Polish)

61. Edman, T.; Angelstam, P.; Mikusiński, G.; Roberge, J.-M.; Sikora, A. Spatial Planning for Biodiversity Conservation: Assessment of Forest Landscapes' Conservation Value Using Umbrella Species Requirements in Poland. Landsc. Urban. Plan. 2011, 102, 16-23. [CrossRef]

62. Rocznik Statystyczny Leśnictwa 1971 [Forestry Statistical Yearbook 1971]; GUS: Warsaw, Poland, 1971. Available online: https: / / stat.gov.pl/ (accessed on 11 November 2021). (In Polish)

63. Skolud, P. Zalesianie Gruntów Rolnych i Opuszczonych Terenów Rolniczych-Poradnik Właściciela [Afforestation of Agricultural Land and Abandoned Agricultural Sites-An Owner's Guide], 2nd ed.; CILP: Warsaw, Poland, 2008; ISBN 978-83-89744-82-1. (In Polish)

64. Tahvanainen, L.; Tyrväinen, L.; Ihalainen, M.; Vuorela, N.; Kolehmainen, O. Forest Management and Public Perceptions-Visual versus Verbal Information. Landsc. Urban. Plan. 2001, 53, 53-70. [CrossRef]

65. Szafer, W. Zarys historii ochrony przyrody w Polsce [Outline of the history of nature conservation in Poland]. In Ochrona Przyrody i jej Zasobów-Problemy i Metody [Conservation of Nature and Its Resources_Problems and Methods]; Szafer, W., Ed.; ZOP PAN: Kraków, Poland, 1965; Volume 1, pp. 53-123. (In Polish)

66. Szafer, W. Rezerwaty w Polsce [Reserves in Poland]. In Skarby Przyrody i ich Ochrona [Natural Treasures and Their Protection]; Szafer, W., Ed.; PROP: Warsaw, Poland, 1932; pp. 294-317. (In Polish)

67. Denisiuk, Z.; Pilipowicz, W.; Przybylski, J. Ocena aktualnego stanu rezerwatów [Assessment of the current status of nature reserves]. In Ochrona Rezerwatowa w Polsce-Stan Aktualny i Kierunki Rozwoju [Reserve Protection in Poland—Current Status and Development Directions]; Studia Naturae; ZN im. Ossolińskich: Wrocław, Poland, 1990; Volume 35, pp. 17-29, ISBN 83-04-03699-1. (In Polish)

68. Rocznik Statystyczny Leśnictwa i Przemysłu Drzewnego 1961 [Statistical Yearbook of Forestry and Wood Industry 1961]; PWRiL: Warsaw, Poland, 1963. Available online: https:/ / stat.gov.pl/ (accessed on 11 November 2021). (In Polish)

69. Ochrona Środowiska [Environment]. Statistical Yearbook of 1989; GUS: Warsaw, Poland, 1989. Available online: https://stat.gov.pl/ (accessed on 11 November 2021).

70. Ochrona Środowiska [Environment]. Statistical Yearbook of 2000; GUS: Warsaw, Poland, 2001. Available online: https://stat.gov.pl/ (accessed on 11 November 2021).

71. Leśnictwo [Forestry]. Statistical Yearbook of 2001; GUS: Warsaw, Poland, 2002. Available online: https://stat.gov.pl/ (accessed on 11 November 2021).

72. Referowska-Chodak, E. Skala i intensywność ochrony przyrody w lasach [Scale and intensity of nature conservation in forests] In Problemy Ochrony Przyrody w Lasach [Problems of Nature Conservation in Forests]; IBL: Sękocin Stary, Poland, 2010; pp. 291-313, ISBN 978-83-87647-91-9.

73. Leśnictwo [Forestry]. Statistical Yearbook of 2011; GUS: Warsaw, Poland, 2012. Available online: https://stat.gov.pl/cps/rde/xbcr/ gus/rl_lesnictwo_2012.pdf (accessed on 15 June 2021).

74. Referowska-Chodak, E. Ochrona Przyrody w Lasach Państwowych-Potrzeby i Oczekiwania Różnych Grup Społecznych Oraz ich Konsekwencje [Nature Protection in the State Forests-Needs and Expectations of Various Social Groups and Their Consequences], 1st ed.; SGGW: Warsaw, Poland, 2020; ISBN 978-83-7583-976-0.

75. GDOŚ Geoserwis Maps-Maps of Poland with Nature Protection Areas. Available online: http://geoserwis.gdos.gov.pl/mapy/ (accessed on 24 November 2021). 
76. Blicharska, M.; Angelstam, P.; Elbakidze, M.; Axelsson, R.; Skorupski, M.; Węgiel, A. The Polish Promotional Forest Complexes: Objectives, Implementation and Outcomes towards Sustainable Forest Management? For. Policy Econ. 2012, 23, 28-39. [CrossRef]

77. Warchalska-Troll, A. Natura 2000 Sites in the Polish Carpathians vs Local Development: Inevitable Conflict? Ecomont 2018, 10, 50-58. [CrossRef]

78. Gołos, P.; Kaliszewski, A. Społeczne i ekonomiczne uwarunkowania realizacji publicznych funkcji lasu w Państwowym Gospodarstwie Leśnym Lasy Państwowe [Social and economic conditions for providing public forest services in the State Forests National Forest Holding]. Sylwan 2016, 160, 91-99. [CrossRef]

79. Ochrona Środowiska [Environment]. Statistical Yearbook of 1990; GUS: Warsaw, Poland, 1991. Available online: https://www. worldcat.org/title/ochrona-srodowiska/oclc/1112389282 (accessed on 15 June 2021).

80. Nowakowska, J.; Orzechowski, M. Lasy ochronne w Polsce-zarys historii na tle Europy [Protective forests in Poland—an outline of history in comparison to Europe]. Sylwan 2018, 162, 598-609. [CrossRef]

81. Regulation on Detailed Rules and Procedures for Recognizing Forests as Protective and Detailed Rules for Forest Management in Them, 1992 [Dz.U. 1992.67.337, in Polish]. Available online: http:/ / isap.sejm.gov.pl/isap.nsf/download.xsp/WDU19920670337 /O/D19920337.pdf (accessed on 6 May 2018).

82. Rocznik Statystyczny Leśnictwa i Gospodarki Drewnem 1981 [Statistical Yearbook of Forestry and Wood Economy]; GUS: Warsaw, Poland, 1981. Available online: http:/ /agro.icm.edu.pl/agro/element/bwmeta1.element.agro-f4ba2e50-20e1-487c-98a0-11abbef6d14e/c/ 1-10.pdf (accessed on 15 June 2021). (In Polish)

83. Babiński, S.; Białkiewicz, F.; Krajewski, T. Stan melioracji wodnych w lasach [State of water reclamation in forests]. Zesz. Probl. Postępu Nauk Rol. 1989, 375, 127-138.

84. Jasnowski, M. Aktualny stan i program ochrony torfowisk w Polsce [Current status and conservation programme for peatlands in Poland]. Chrońmy Przyr. Ojczysta 1977, 33, 18-29.

85. CBD Convention: The Convention on Biological Diversity, Adopted on 5 June 1992 in Rio de Janeiro. Polish Version: 1995 [Dz. U. 1995.118.565, 2002.184.1532]. Available online: http:/ /isap.sejm.gov.pl/isap.nsf/DocDetails.xsp?id=WDU19951180565 (accessed on 10 November 2021).

86. Ramsar Convention: Convention on Wetlands, Adopted on 2 February 1971 in Ramsar. Polish Version: 1978 [Dz. U. 1978.7.24-25]. Available online: http://isap.sejm.gov.pl/isap.nsf/DocDetails.xsp?id=WDU19780070024 (accessed on 10 November 2021).

87. Czerniak, A.; Grajewski, S.; Krysztofiak-Kaniewska, A.; Kurowska, E.E.; Okoński, B.; Górna, M.; Borkowski, R. Engineering Methods of Forest Environment Protection against Meteorological Drought in Poland. Forests 2020, 11, 614. [CrossRef]

88. Stepniewska, M.; Zwierzchowska, I.; Mizgajski, A. Capability of the Polish Legal System to Introduce the Ecosystem Services Approach into Environmental Management. Ecosyst. Serv. 2018, 29, 271-281. [CrossRef]

89. The Nature Conservation Act, 2004 [Dz. U. 2004.92 .880 as amended, in Polish]. Available online: http:/ / isap.sejm.gov.pl/isap. nsf/download.xsp/WDU20040920880/U/D20040880Lj.pdf (accessed on 20 March 2020).

90. Grupa Robocza FSC-Polska Kryteria Wyznaczania Lasów o Szczególnych Walorach Przyrodniczych (High Conservation Value Forests) w Polsce 2006. Available online: https:/ / pl.fsc.org/sites/default/files/2021-04/Kryteria\%20wyznaczania\%20Las\%C3 \%B3w \%20o\%20szczeg\%C3\%B3lnych\%20walorach\%20przyrodniczych $\% 20 \% 28 \mathrm{HCVF} \% 29 \% 20 \mathrm{w} \% 20 \mathrm{Polsce}$.pdf\#viewer.action= download (accessed on 15 June 2021).

91. FSC Poland The Website of the FSC Certification Scheme in Poland. Available online: http:/ / pl.fsc.org (accessed on 17 December 2020).

92. Instrukcja Urządzania Lasu [Forest Management Planning Instruction]; Święcicki, Z. (Ed.) CILP: Warsaw, Poland, $2012 ;$ Volume 1. Available online: https:/ / www.lasy.gov.pl/pl/publikacje/copy_of_gospodarka-lesna/urzadzanie/iul/zarzadzenie-nr-83-201 2/view (accessed on 11 November 2021)ISBN 978-83-61633-69-3. (In Polish)

93. Jaworski, A. Sposoby Zagospodarowania, Odnawianie Lasu, Przebudowa i Przemiana Drzewostanów [Management Practices, Regeneration, Conversion and Transformation of Forest Stands], 2nd ed.; Hodowla lasu [Silviculture]; PWRiL: Warsaw, Poland, 2018; Volume 1, ISBN 978-83-09-01113-2. (In Polish)

94. Csóka, P. Capital Management-The Forests in Countries in Transition-Welfare Impacts. In Forestry and Environmental Change: Socioeconomic and Political Dimensions; Report No.5 of the IUFRO Task Force on Environmental Change; Innes, J.L., Hickey, G.M., Hoen, H.F., Eds.; CABI: Wallingford, CT, USA, 2005; pp. 125-141, ISBN 978-0-85199-002-6.

95. Kuemmerle, T.; Hostert, P.; Radeloff, V.C.; Perzanowski, K.; Kruhlov, I. Post-Socialist Forest Disturbance in the Carpathian Border Region of Poland, Slovakia, and Ukraine. Ecol. Appl. 2007, 17, 1279-1295. [CrossRef]

96. Durak, T.; Holeksa, J. Biotic Homogenisation and Differentiation along a Habitat Gradient Resulting from the Ageing of Managed Beech Stands. For. Ecol. Manag. 2015, 351, 47-56. [CrossRef]

97. Griffiths, P.; Kuemmerle, T.; Baumann, M.; Radeloff, V.C.; Abrudan, I.V.; Lieskovsky, J.; Munteanu, C.; Ostapowicz, K.; Hostert, P. Forest Disturbances, Forest Recovery, and Changes in Forest Types across the Carpathian Ecoregion from 1985 to 2010 Based on Landsat Image Composites. Remote Sens. Environ. 2014, 151, 72-88. [CrossRef]

98. Broda, J. Lasy Państwowe w Polsce w Latach 1944-1990 [State Forests in Poland 1944-1990], 1st ed.; Broda, J., Ed.; PWN: WarsawPoznań, Poland, 1997; ISBN 83-01-12359-1.

99. Referowska-Chodak Management and Social Problems Linked to the Human Use of European Urban and Suburban Forests. Forests 2019, 10, 964. [CrossRef] 
100. Dudek, T.; Zięba, W. Wybrane aspekty zrównoważonego użytkowania lasu w nawiązaniu do programu zrównoważonego rozwoju-przykład Polski [Selected aspects of sustainable forest utilization with regard to the sustainable development programPolish example]. Sylwan 2018, 162, 469-478. [CrossRef]

101. The Strategic Resources Act, 2001 [Dz. U. 2001.97.1051 as Amended]. Available online: http://isap.sejm.gov.pl/isap.nsf/ DocDetails.xsp?id=WDU20010971051 (accessed on 4 March 2020). (In Polish)

102. Lindner, M.; Maroschek, M.; Netherer, S.; Kremer, A.; Barbati, A.; Garcia-Gonzalo, J.; Seidl, R.; Delzon, S.; Corona, P.; Kolström, M.; et al. Climate Change Impacts, Adaptive Capacity, and Vulnerability of European Forest Ecosystems. For. Ecol. Manag. 2010, 259, 698-709. [CrossRef]

103. Szwagrzyk, J.; Gazda, A.; Dobrowolska, D.; Chećko, E.; Zaremba, J.; Tomski, A. Tree Mortality after Wind Disturbance Differs among Tree Species More than among Habitat Types in a Lowland Forest in Northeastern Poland. For. Ecol. Manag. 2017, 398, 174-184. [CrossRef]

104. Grajewski, S. Effectiveness of Forest Fire Security Systems in Poland. Infrastruktura i Ekologia Terenów Wiejskich 2017, IV/2, 1563-1576. [CrossRef]

105. Durak, T. Long-Term Trends in Vegetation Changes of Managed versus Unmanaged Eastern Carpathian Beech Forests. For. Ecol. Manag. 2010, 260, 1333-1344. [CrossRef]

106. Directorate-General of the State Forests. Sprawozdanie Finansowo-Gospodarcze za 2016 rok [Report on Financial and Economic State of State Forests in 2016]; DGLP: Warsaw, Poland, 2017; p. 43.

107. Directorate-General of the State Forests. Sprawozdanie Finansowo-Gospodarcze za 2009 rok [Report on Financial and Economic State of State Forests in 2009]; DGLP: Warsaw, Poland, 2010; p. 34.

108. Directorate-General of the State Forests. Sprawozdanie Finansowo-Gospodarcze za 2013 rok [Report on Financial and Economic State of State Forests in 2013]; DGLP: Warsaw, Poland, 2014; p. 46.

109. Directorate-General of the State Forests. Sprawozdanie Finansowo-Gospodarcze za 2014 rok [Report on Financial and Economic State of State Forests in 2014]; DGLP: Warsaw, Poland, 2015; p. 46.

110. Directorate-General of the State Forests. Sprawozdanie Finansowo-Gospodarcze za 2015 rok [Report on Financial and Economic State of State Forests in 2015]; DGLP: Warsaw, Poland, 2016; p. 40.

111. Directorate-General of the State Forests. Sprawozdanie Finansowo-Gospodarcze za 2017 rok [Report on Financial and Economic State of State Forests in 2017]; DGLP: Warsaw, Poland, 2018; p. 49.

112. Directorate-General of the State Forests. Sprawozdanie Finansowo-Gospodarcze za 2018 rok [Report on Financial and Economic State of State Forests in 2018]; DGLP: Warsaw, Poland, 2019; p. 45.

113. Resolution No. 239 of the Council of Ministers of 13 December 2011 “Concept of Spatial Planning of the Country 2030 ”, 2011 [M. P. 2012.0.252, in Polish]. Available online: http:/ / isap.sejm.gov.pl/isap.nsf/DocDetails.xsp?id=WMP20120000252 (accessed on 10 October 2021).

114. Raši, R.; Schwarz, M. Pilot Study: Forest Fragmentation Indicator, 1st ed.; FOREST EUROPE Liaison Unit Bratislava: Zvolen, Slovakia, 2019; ISBN 978-80-8093-300-5.

115. Pan, Y.; Birdsey, R.A.; Phillips, O.L.; Jackson, R.B. The Structure, Distribution, and Biomass of the World's Forests. Annu. Rev. Ecol. Evol. Syst. 2013, 44, 593-622. [CrossRef]

116. Lehvävirta, S. Non-Anthropogenic Dynamic Factors and Regeneration of (Hemi)Boreal Urban Woodlands-Synthesising Urban and Rural Ecological Knowledge. Urban. For. Urban. Green. 2007, 6, 119-134. [CrossRef]

117. Golivets, M. Ecological and Biological Determination of Invasion Success of Non-Native Plant Species in Urban Woodlands with Special Regard to Short-Lived Monocarps. Urban. Ecosyst. 2014, 17, 291-303. [CrossRef]

118. Fischer, J.; Lindenmayer, D.B. Landscape Modification and Habitat Fragmentation: A Synthesis. Glob. Ecol. Biogeogr. 2007, 16, 265-280. [CrossRef]

119. Keinath, D.A.; Doak, D.F.; Hodges, K.E.; Prugh, L.R.; Fagan, W.; Sekercioglu, C.H.; Buchart, S.H.M.; Kauffman, M. A Global Analysis of Traits Predicting Species Sensitivity to Habitat Fragmentation: Species Sensitivity. Glob. Ecol. Biogeogr. 2017, 26, 115-127. [CrossRef]

120. Ledig, F.T. Human Impacts on Genetic Diversity in Forest Ecosystems. Oikos 1992, 63, 87-108. [CrossRef]

121. Zielony, R.; Kliczkowska, A. Regionalizacja Przyrodniczo-Leśna Polski 2010 [Natural-Forest Regionalization of Poland 2010]; CILP: Warsaw, Poland, 2012; ISBN 978-83-61633-62-4. (In Polish)

122. Zasady Hodowli Lasu [Silvicultural Principles], 1st ed.; Haze, M. (Ed.) CILP: Warsaw, Poland, 2012; ISBN 978-83-61633-65-5. Available online: https://www.lasy.gov.pl/pl/pro/publikacje/copy_of_gospodarka-lesna/hodowla/zasady-hodowli-lasudokument-w-opracowaniu, (accessed on 11 November 2021). (In Polish) 